\title{
Historický přehled principů tvorby metod pro odhad výšky postavy člověka na základě skeletu
}

\author{
Tomáš Zeman, Miroslav Králík \\ Ústav antropologie Př́rodovědecké fakulty Masarykovy univerzity, Kotlářská 2, 61137 Brno
}

Do redakce doručeno 17. března 2012; k publikaci přijato 21. května 2012

\section{A HISTORICAL REVIEW OF PRINCIPLES GUIDING THE FORMULATION OF METHODS FOR STATURE ESTIMATION BASED ON THE HUMAN SKELETON}

\begin{abstract}
A historical review of principles guiding the formulation of methods for stature estimation based on measurements of the human skeleton reveals that it is possible to delimit four basic groups of methods: anatomical, constant ratio, linear regression, and organic correlation methods. Each has its own specific features and limits, which are a result of their mathematical constructions. Long bones of limbs are most often used for estimates of stature. It was demonstrated theoretically that linear regression models provide the most precise and accurate estimates of stature from particular skeletal elements, especially when several suitable bones are used in combination. A necessary condition for using the linear regression equations is, however, that we use equations based on the population from which the estimated individual originated. In contrast, when a regression equation is applied to an individual originating from a different population smaller or larger systematic error of the estimate may result. This fact was assessed empirically on numerous occasions and it was demonstrated on the basis of linear regression theory that a phenomenon known as "regression to the mean" can be considered as the cause. Organic correlations (built on the least-triangle area criterion) are less prone to systematic errors, but they are also less precise. They can be applied to any population and are best suited for cases where the population of origin is unknown. Anatomical methods are best applied when the skeleton is adequately preserved as this method requires bone lengths of all (or almost all) bones contributing to body height. The difference between height of the living body and the sum of lengths of relevant bones from head to heel is in the order of centimeters so the estimate error margin is small. Consequently, the differences between estimates obtained from using the different mathematical approaches (constant ratio, linear regression or organic correlation) are insignificant, so there is little benefit in preferring any particular one. Overall, anatomical methods provide the most accurate and precise results for height estimation and should be recommended wherever allowed by the state of preservation of the skeleton.
\end{abstract}

KEY WORDS stature estimation; historical review; constant ratio methods; linear regression; organic correlation; anatomical methods

\begin{abstract}
ABSTRAKT Z historického přehledu principů tvorby metod pro odhad výšky postavy člověka na základě skeletu vyplývá, že lze vymezit čtyři základní skupiny metod: metody podílové, regresní, anatomické a metody organické korelace. Každá má svá specifika a úskalí, která bezprostředně vyplývají z jejich matematické konstrukce. Nejčastěji se k odhadu výšky postavy používají některé rozměry dlouhých kostí končetin. Bylo teoreticky prokázáno, že nejpřesnější možné odhady poskytují metody regresní, zejména když k odhadu využijeme kombinaci rozměrů $\mathrm{z}$ více kostí. Nutným předpokladem použití lineární regrese je však užití pouze těch rovnic, které byly vytvořeny na základě výběru z populace, $\mathrm{z}$ níž pochází i odhadovaný jedinec. $V$ opačném př́ipadě, tj. pokud je lineární regrese použita pro odhad jedinců z populace jiné, může dojít $\mathrm{k}$ menšímu či většímu vychýlení odhadu. Tato skutečnost byla již mnohokrát empiricky ověřena. Teoretický rozbor lineární regrese ukázal, že jde o důsledek jevu označovaného jako „regrese k průměru“. Metody organické korelace (založené na minimalizaci součtu plochy reziduálních trojúhelníků) jsou méně náchylné k systematické chybě, jsou však také méně přesné. Lze je ale aplikovat na libovolnou populaci a pro jednotlivé př́ípady $\mathrm{z}$ neznámé populace jsou nejpřesnější. Anatomické metody jsou aplikovatelné jen v př́padě dostatečně zachovaného skeletu. Jsou založeny na součtu výšek všech (nebo téměř všech) kostí skeletu, které se na výšce postavy přímo podílejí. Rozdíl mezi výškou postavy za života a součtem délek kostí skeletu od lebky po patní kost se pohybuje v řádu centimetrů a prostor pro chybu odhadu je tak malý. At už pak k odhadu výšky ze skeletu v rámci anatomické metody použijeme kterýkoliv ze tř́ výše uvedených matematických postupů (podílová metoda, lineární regrese, organická korelace), rozdíly mezi jimi pořízenými odhady jsou zanedbatelné a jejich rozlišování pozbývá smyslu. Celkově jsou tedy anatomické metody nejpřesnější a je třeba je doporučit, kdykoliv to stav zachování skeletu dovolí.
\end{abstract}

KLÍČOVÁ SLOVA odhad výšky postavy; historický přehled; podílové metody; lineární regrese; organická korelace; anatomické metody 


\section{ÚVOD}

Zájem odhadovat výšku postavy člověka z jeho kosterních pozůstatků sahá do 19. století a je spojen především s úkolem identifikace osob. Vytvořené metody se začaly ihned uplatňovat především $\mathrm{v}$ kriminalistice a archeologii. Využity byly zejména při repatriaci ostatků válečných obětí po druhé světové válce. Výška postavy je i dnes důležitým nástrojem skupinové identifikace kosterních pozůstatků v soudní antropologii ${ }^{1}$. Za více než 150 let vzniklo velké množství metod, přesto ani dnes není odhad výšky postavy na základě kostry bez potíží. Odhady pořízené různými metodami se mohou lišit i o desítky centimetrů (Duyar, Pelin 2010). Je proto nezbytné usilovat o odhalení př́ćčin, které k takto vychýleným odhadům vedou. Velká pozornost byla $\mathrm{v}$ minulosti věnována problému reprezentativnosti referenčního souboru. Rösing (1988, s. 590) uvádí zejména, že soubor by měl zahrnovat více než 100 mužů a 100 žen, jejich dožitý věk by měl odpovídat rozdělení věku v populaci, která je předmětem odhadu, mělo by být známo, zda referenční soubor pochází z populace, která prošla sekulárním trendem či nikoliv, měl by mít pestrou sociální strukturu a $\mathrm{v}$ neposlední řadě by se neměl skládat pouze ze zástupců některé úzce specializované profese (např. vojáků, či studentů). Dodržování těchto doporučení má snížit riziko chybného odhadu. Relevance referenčního souboru je však jen jedním z chybových faktorů. Domníváme se, že minimálně stejně významnou je samotná matematická metodika odhadu. Některé metody pro odhad výšky postavy nemohou být bez zajištění platnosti určitých teoretických předpokladů použity bez rizika zásadních chyb. Tento fakt vyplývá z jejich matematické konstrukce a sebelepší referenční soubor nemůže toto riziko odstranit. Jedinou možností je vyvarovat se jejich nevhodného použití. Považujeme proto za přínosné shrnout a vysvětlit principy těchto metod, formulovat předpoklady jejich použití a poukázat na úskalí s nimi spojená. Téma uvádíme formou retrospektivního přehledu, což nám umožňuje také stručně zmínit historické okolnosti, které k zavedení zmiňovaných metod vedly.

\section{DOBA PŘEDSTATISTICKÁ}

První, kdo se pokusil zachytit proporce lidského těla metricky a tyto výsledky publikoval, byl pravděpodobně chirurg Jean-Joseph Sue (1710-1792), profesor Académie Royale de Chirurgie $^{2}$ a Académie Royale de Peinture et de Sculpture v Pařiži ${ }^{3}$. Byl autorem dnes klasického pojednání o pitevních technikách (Sue 1765), které sám podstatně rozpracoval. Není

1 Je součástí tzv. Velké čtyřky soudní antropologie (anglicky Big Four), patří do ní pohlaví, výška postavy, dožitý věk a populační afinita (Novotný et al. 1993).

2 francouzská Královská akademie chirurgů, dnes Académie Nationale de Médecine

3 francouzská Královská akademie maliřství a sochařství, dnes jako Académie des beaux-arts součástí Institute de France proto divu, že i svůj výzkum proporcionality provedl právě na pitevním materiálu (Sue 1750). Metodicky je jeho dílo prŕíznačné pro dobu, v níž vznikalo. Celý výzkum byl proveden bez užití jakýchkoliv statistických veličin, včetně průměru. Jak sám píše „(...) il a fallu choisir avec tout l’attention possible, des sujets bien conformés, et dont la taille ne me parut ni fort grande, ni fort petit, suivant lâge oú les examinois (Sue 1750, s. 573) ${ }^{4}$." Výzkum prováděl se záměrem porovnat vývoj proporcí těla $\mathrm{v}$ průběhu růstu. Ideálního představitele jednotlivých věkových kategorií vybíral pouze na základě svých dosavadních zkušeností z pitev. Sám uznával, že nemá „(...) aucune règle sûre pour choisir cet état moyen ${ }^{5}$ (Sue 1750, s. 573).“ Domníval se však, že jeho odborná intuice je dostatečně spolehlivým nástrojem. Jeho přístup je však vědecký, nebot výsledky neinterpretuje jako závažnější, než ve skutečnosti jsou, a nikterak nepřekračuje možnosti, které skýtá veličina jeho „ideálního jedince“ (z dnešního pohledu se jedná o modus). Výstupem jeho studie byla tabulka, do níž zaznamenal délku trupu, délku horních a dolních končetin a výšku postavy měřenou na pitevním stole (dále v textu délka těla) pro „ideálního jedince" každé věkové kategorie.

Podobně vědecky obezřetně postupovali po téměř stoletém hiátu i jeho následovníci Mathieu Orfila (1787-1853), profesor Faculté de Médecine de Paris ${ }^{6}$, otec toxikologie a jeden z průkopníků francouzské forenzní medicíny, a Octave Lesueur (1802-1860), doktor Faculté de Médecine de Paris. Ve své praktické prríručce Traité des exhumation juridique se okrajově zabývají i posmrtnou výškou člověka (Orfila, Lesueur 1831, s. 380-382). Uvedli zde tabulku, do níž zahrnuli rozměry 51 pitvaných těl. Jejich novátorství spočívalo v tom, že kromě délek tělesných segmentů, jak je měřil dřive Sue (1750), změřili u každého jedince i délky některých kostí. Jmenovitě šlo o kost stehenní, holenní, lýtkovou, pažní, loketní a vřetenní (tj. dlouhé kosti končetin), tyto kosti budou dále v textu označovány jako dlouhé kosti. Navíc jejich kolega doktor Chambroty sestavil 20 skeletů bez měkkých tkání a změřil jejich délku spolu s délkami dlouhých kostí. Orfila s Lesueurem (1831, s. 380) si tak mohli učinit určitou představu o rozdílech mezi délkou pitvaného těla a délkou jeho kostry. Zmenšení výšky $\mathrm{v}$ důsledku absence měkkých tkání odhadli na 1,5 až 2 palce (asi $4-5 \mathrm{~cm}$ ). Ty bylo nutné prri odhadu výšky postavy $\mathrm{k}$ délce kostry připočíst. V situacích, kdy nebyl k dispozici kompletní skelet, se nabízelo využití tabulek s délkami dlouhých kostí. Sami Orfila $s$ Lesueurem se ovšem k podobné praxi stavěli rezervovaně, „(...) parce que nous craindrions qu'on ne nous accusàt de vouloir précise en quelque sorte mathématiquemant la taille dun individu, d'après la longueur d’un ou de pluisieurs os ${ }^{7}$ (Orfila, Lesueur 1931, s. 381). “Připustili sice takový odhad výšky postavy, ovšem pouze jako orientační.

4 (...) bylo třeba vybrat se vší pozorností jedince dobře stavěné, kteří nebyli vzhledem ke svému věku príliš velcí ani malí.

5 (...) jasně stanovené pravidlo pro výběr toho, co jest prostřední.

6 Lékařská fakulta Pařížské univerzity

7 (...) jelikož máme obavy, že bychom byli obviněni z toho, že chceme přsesně stanovovat výšku jedince na základě délky jedné nebo více kostí. 


\begin{tabular}{|c|c|c|c|c|c|}
\hline \multicolumn{6}{|c|}{ Longueur maximum des os longs. } \\
\hline Nombre de sujets. & Taille moyenne. & Bumérus. & Radius. & Fomur. & Tibia. \\
\hline 22 hommes........ & 1.77 & 350 & 255 & 490 & 397 \\
\hline $29-\ldots . . .$. & 1.65 & 332 & 241 & 457 & 368 \\
\hline$\ldots \ldots \ldots$ & 1.56 & 314 & 227 & 124 & 339 \\
\hline 25 Femmes ......... & 1.53 & 304 & 219 & 421 & 335 \\
\hline
\end{tabular}

Tabulka I: Topinardova tabulka délek dlouhých kostí (1885a, 474). Topinard rozdělil svůj soubor do 4 skupin podle průměrné výšky postavy (Taille moyenne). Pro každou skupinu uvádí dále maximální délky (M1) těchto dlouhých kostí: humerus (Humérus), radius (Radius), femur (Fémur) a tibia (Tibia). Všimněme si, že nejvyšší skupina je tvořena pouze muži (hommes), skupina nejnižší pak pouze ženami (femmes).

O půl století později si Orfila ${ }^{8}$ za svůj prrístup vysloužil tvrdou kritiku otce vývojové antropologie Paula Topinarda (1830-1911), profesora a zastupujícího ředitele Laboratoire d'Anthropologie 9 . Ten ve svém stěžejním díle Éléments d’anthropologie générale ${ }^{10}$ upozornil na skutečnost, že navzdory Orfilově a Lesueurově skepsi (1831, s. 381) ohledně praktické hodnoty jejich tabulek pro odhady výšky postavy, byly tyto tabulky běžně užívány nejen archeology, ale i soudními lékaři (Topinard 1885a, s. 473). Topinard zde uvádí, že výška postavy bývá odhadována bud' konfrontací délky některé dlouhé kosti s délkami zjištěnými Orfilou a Lesueurem u jejich vzorku nebo spočtením průměru délek více dlouhých kostí a jejich porovnáním $s$ analogicky stanovenými průměry $u$ tabelovaných jedinců. Zejména však dával Orfilovi za vinu, že nepopsal způsob, jakým jednotlivé dlouhé kosti měřil, což podkopává věrohodnost jakéhokoliv odhadu založeného na jeho datech. Aby tyto závady odstranil, vypitval Topinard 23 těl, kostry bez měkkých tkání znovu složil a změřil jejich délku. Rozdíl mezi ní a původní délkou těla činil asi $3,5 \mathrm{~cm}$. To mu umožnilo rozšírit svůj soubor o dalších 74 jedinců s neznámou délkou těla. Jejich skelety sestavil, změřil a $\mathrm{k}$ této délce připočítal zmíněných $3,5 \mathrm{~cm}$, aby kompenzoval chybějící měkké tkáně. Jedince rozřadil do čtyř kategorií podle délky těla a pro každou z nich uvedl průměrné hodnoty jednotlivých rozměrů (tabulka I). Odhady tak již nebyly prováděny na základě tabelovaných hodnot jednotlivců, jako tomu bylo v Orfilově a Lesueurově tabulce (1831, s. 389), nýbrž na základě průměrných délek pro skupiny více než 20 jedinců. Topinard konstatoval (1885a, s. 473), že bude třeba shromáždit mnohem větší vzorek a ve stejném roce zveřejnil návod (Topinard 1885b, s. 472-475), jak standardně měřit dlouhé kosti pro odhad výšky postavy. Obecně doporučoval použití

8 Na Lesuerovo spoluautorství se mezitím zapomnělo a ani Topinard (1885a, s. 473), ani žádný z později píśících autorů se již o něm nezmiňují.

9 Laboratoř antropologie, vznikla roku 1868 při École pratique des Hautes-Études v Paříži z iniciativy Paula Brocy (1824-1880). Ten se stal také jejím prvním ředitelem.

10 Jde o př́ručku antropologie, která vznikla syntézou tehdejšího stavu poznání. Vychází zejména $\mathrm{z}$ poznatků okruhu antropologů okolo Paula Brocy (1824-1880) soustředěných v Laboratoire d'Anthropologie. maximálních rozměrů dlouhých kostí pro jejich snadné měření a vyšší přesnost při použití Brocovy osteometrické desky oproti složitěji definovaným rozměrům.

Podobně se vyvíjela situace v Anglii, kde chirurg George Murray Humphry (1820-1896), profesor Univerzity of Cambridge $^{11}$, změřil 25 dospělých a 29 dětských skeletů (Humphry 1858 , s. 85-112). Stejně jako Topinard a Orfila měřil i on délku skeletů po jejich sestavení. Provedl přitom ale jednu inovaci: Označme typ dlouhé kosti $B$, její délku $X_{B}$ a výšku postavy $Y$. Humphry vyjádřil průměrnou délku každé dlouhé kosti $\bar{x}_{B}=E\left(X_{B}\right)$ jako procento z průměrné výšky postavy $\bar{y}=E(Y)$. Oproti orientační tabulce Orfilově tak nabízí možnost výpočtu výšky postavy jednoduchým dopočtem do sta procent pomocí trojčlenky. Odhad výšky postavy ŷ pro délku dlouhé kosti $x_{B}$ lze tedy vyjádřit

$$
\hat{\mathrm{y}}=\frac{\bar{y}}{\bar{x}_{B}} x_{B}=c_{B} x_{B} .
$$

To odpovídá rovnici přímky procházející počátkem se směrnicí $c_{B}$. Stejný princip začlenil do své metody později i Topinard (1885a) s tím rozdílem, že každá ze 4 skupin, které vyčlenil, měla vlastní $c_{B}$ a pro odhad výšky postavy se využívalo $c_{B}$ skupiny, jejíž $\bar{x}_{B}$ byla nejblíže délce dlouhé kosti, z níž byla výška postavy odhadována. Dále budeme o těchto typech metod hovořit jako o metodách podílových.

Pro podílové metody je charakteristické řazení jedinců podle výšky postavy, což maskuje jev označovaný jako regrese $k$ průméru ${ }^{12}$. Tento jev popsal Galton (1886) až rok po uveřejnění Topinardovy studie (1885a, s. 472-475) a ani on ani dříve Humphry (1858, s. 85-112) ji ve svých metodách nezohlednili patrně proto, že o její existenci neměli vůbec tušení. To nutně vedlo k systematickému podhodnocování odhadů výšky postavy u jedinců s podprůměrnou délkou dlouhých kostí, resp. nadhodnocování u jedinců s délkou nadprůměrnou, při použití těchto metod (schéma I). Toho si povšiml viktoriánský lékař John Beddoe (1826-1911), člen Royal Society ${ }^{13}$. Je zřejmé, že o Galtonově (1886) regresi k průměru bud' neslyšel, nebo ji nebere do úvahy a celý jev vysvětluje ryze biologicky: „(...) common observation teaches us that short men have, as a rule, shorter legs in proportion than tall men; and it would seem that this applies to both femur and tibia. Hence the indiscriminate application of Humphry's proportions must, in a series sufficiently large to swamp the exceptions, bring out an unduly low stature for short men, and an unduly high one for tall men, thus exaggerating the actual differences ${ }^{14}$ (Beddoe 1888,

\section{Cambridgeská univerzita}

\section{2 vysvětlení na schématu I}

13 Královská společnost, což je společenství nejpřednějších osobností ze všech oblastí vědy.

14 (...) běžné pozorování nás učí, že lidé nízkého vzrůstu mají zpravidla relativně kratší dolní končetiny než lidé vysocí, a zdá se, že to platí pro femur i tibii. Tudíž nekritické použití Humphryho proporcí musí v dostatečně velkém souboru, kde se ztratí výjimky, přinášet nepatřičně nízké postavy pro malé lidi a nepatřičně vysoké pro vysoké lidí, čímž nadsazují skutečné rozdíly mezi nimi. 


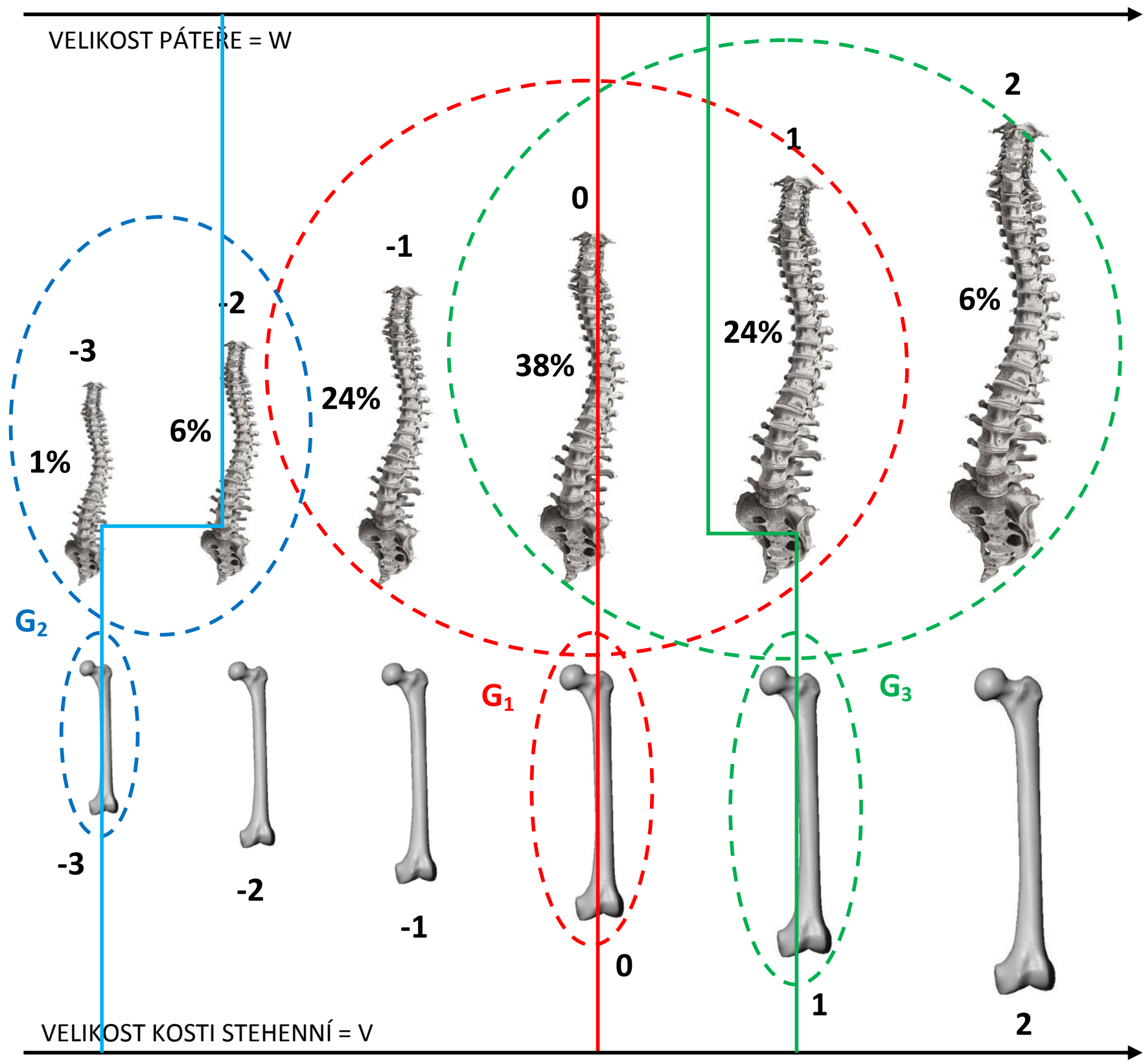

SCHÉMA I: Předpokládejme, že délka kosti stehenní $X_{F}$ a délka páteře $X_{S}$ jsou normálně rozdělené náhodné veličiny $\left(X_{F} \sim N\left(\mu_{F}, \sigma_{F}^{2}\right) ; X_{S} \sim N\left(\mu_{S}, \sigma_{S}^{2}\right)\right)$. Definujme:

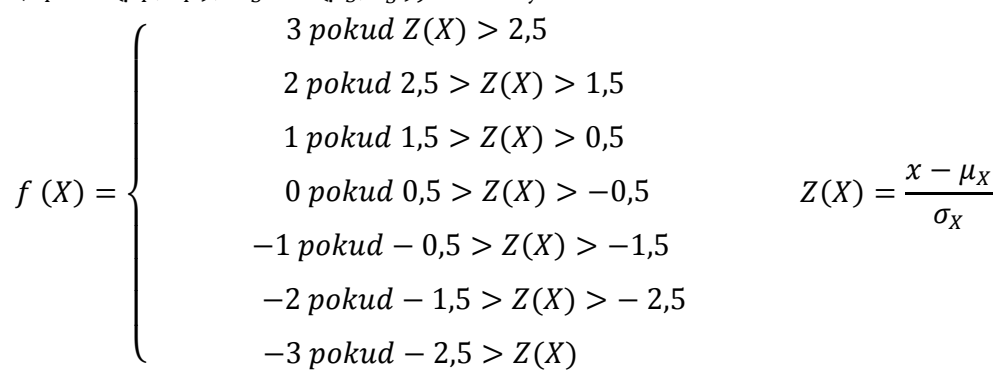

Potom transformovanou náhodnou veličinu $V=f\left(X_{F}\right)$ nazvěme velikost kosti stehenní a $W=f\left(X_{S}\right)$ velikost páteře. Všimněme si, že hodnoty pravděpodobnostní funkce $\pi(v)=P(V=v)$ a $\pi(w)=P(W=w)$ odpovídají hodnotám hustoty pravděpodobnosti pro $x_{F}=\left(v+\mu_{X_{F}}\right) \sigma_{X_{F}}$ a $x_{S}=\left(w+\mu_{X_{S}}\right) \sigma_{X_{S}}$. Potom ale lze $\pi(v)$ a $\pi(w)$ dopočítat $\mathrm{z}$ hustoty pravděpodobnosti standardizovaného normálního rozdělení. Relativní četnosti lidí v jednotlivých velikostních skupinách veličiny $\mathrm{W}$ jsou uvedeny ve schématu v procentech. 
I - - I Vybereme skupinu lidí $G_{1}$ s průměrně velkými kostmi stehenními $(E(V)=0)$. Lze předpokládat, že tito jedinci budou mít $\mathrm{i}$ průměrnou velikost páteře $(E(W)=0)$. Tato závislost ovšem není úplná, ve skupině se tedy objeví i určitý počet jedinců $s$ velikostí páteře -1 (ti budou mít relativně kratší páteř, než je v populaci obvyklé) a velikostí páteře 1 (budou mít relativně delší páteř, než je v populaci obvyklé). $\mathrm{V}$ důsledku toho bude mít rozdělení velikosti páteře v takové skupině $\left(\mathrm{G}_{1}\right)$ vyčší rozptyl, než rozdělení velikosti kosti stehenní $(D(V)<D(W))$.

I Vybereme nyní skupinu lidí $\mathrm{G}_{2} \mathrm{~s}$ nejmenšími stehenními kostmi $(\mathrm{E}(\mathrm{V})=-3)$. Platí zřejmě stejný princip, jako v předchozím výběru, ovšem jedinci s menším trupem, než bychom očekávali, zde neexistují. V naší skupině budou v důsledku toho zastoupeni pouze jedinci s velikostí páteře $-3 \mathrm{a}-2$. Tedy i průměrná velikost páteře bude ležet někde mezi těmito hodnotami $(-3<E(W)<-2)$. Průměrná velikost kostí stehenních ve skupině je ovšem $-3(\mathrm{E}(\mathrm{V})=-3)$. To znamená, že kromě $D(V)<D(W)$ platí i $E(V)<E(W)$. A to je regrese $\mathrm{k}$ průměru.

I Vybereme nakonec skupinu lidí $G_{3}$ s nadprůměrnými stehenními kostmi $(E V=1)$. Mohlo by se zdát, že se bude opakovat situace $\bar{z}$ prvního př́kladu, musíme si ovšem uvědomit, že délka páteře $Y$ je normálně rozdělena. To znamená, že jedinců, jejichž délka páteře se blíží délce průměrné $(|y-E Y|<\varepsilon)$, je v populaci vždy více, nežli jedinců s délkou páteře vzdálenější od průměru $(\varepsilon<|\mathrm{y}-\mathrm{EY}|)$. Tomu odpovídá i rozdělení velikosti páteře $\mathrm{W}$ vyjádřené ve schématu v procentech. $\mathrm{V}$ důsledku toho musí být průměrná velikost páteře menší než 1 $(E(W)<1)$. Platí tedy $E(V)>E(W)$.

Regrese k průměru je tedy jev, kdy populační průměrná hodnota neselektovaného znaku $\left(\mathrm{EW}_{\mathrm{i}}\right)$ pro libovolnou podskupinu $\left(\mathrm{G}_{\mathrm{i}}\right)$ vybranou z populace je vzhledem ke svému rozptylu relativně blíže k populačnímu průměru tohoto znaku (EW), nežli je průměrná hodnota znaku podskupiny $\left(\mathrm{EV}_{\mathrm{i}}\right)$, podle jehož velikosti byla tato skupina vybrána, vzdálena populačnímu průměru svému (EV).

s. 202).“Problém řeší zavedením absolutního členu do rovnice př́mky, což jde ruku v ruce $s$ umenšením její směrnice, nebot př́mka musí nadále procházet bodem $\left[\bar{x}_{B}, \bar{y}\right]$. Odhad výšky postavy pak vyjadřuje rovnicí

$$
\hat{y}=33+3 x_{F}
$$

kde $x_{F}$ je maximální délka femuru (M1) v centimetrech. Pokud délka femuru (M1) přesáhne 48 centimetrů, používá rovnici

$$
\hat{y}=33+3 x_{F}+0,5\left(x_{F}-48\right)=9+3,5 x_{F} .
$$

Jiné rovnice Beddoe neuvádí. Pro srovnání (graf I), analogická Humphryho (1858) rovnice má tvar

$$
\hat{y}=3,64 x_{F} \text {. }
$$

Absolutní člen však Beddoe (1888) stanovuje zcela intuitivním zpơsobem bez využití statistických metod.

Beddoe píše (1888, s. 202), že na odhad výšky postavy a „(..) on so many other subjects, Topinard is our principal authority ${ }^{15}$ (...). “ Topinardova svrchovanost měla však již brzy pominout. V témže roce publikoval svou podílovou metodu Etienne Rollet (1862-1937), pozdější profesor očního lékařství Académie Nationale de Médecine ${ }^{16}$. Vytvořil ji na základě délek 100 pitvaných těl o známém věku (Rollet 1888). Všechny dlouhé kosti měřil čerstvé, bezprostředně po vypitvání a poté některé z nich znovu po osmi či deseti měsících již suché. Zjistil, že rozdíl v délce činil asi $2 \mathrm{~mm}$. Stav kostí je tedy třeba zohledňovat. Rolletova metoda (1888) se záhy stala předmětem sváru antropologa Léonce Manouvriera (1850-1927), od roku 1903 ředitele Laboratoire d'Anthropologie, a britského matematika Karla Pearsona (1856-1936), profesora University College London, sváru, který zcela změnil přístup $\mathrm{k}$ metodice odhadu výšky postavy a zapříčinil, že i Rolletova metoda upadla

15 (...) tak mnoha jiných témat je Topinard naši hlavní autoritou. 16 francouzská Národní lékařská akademie

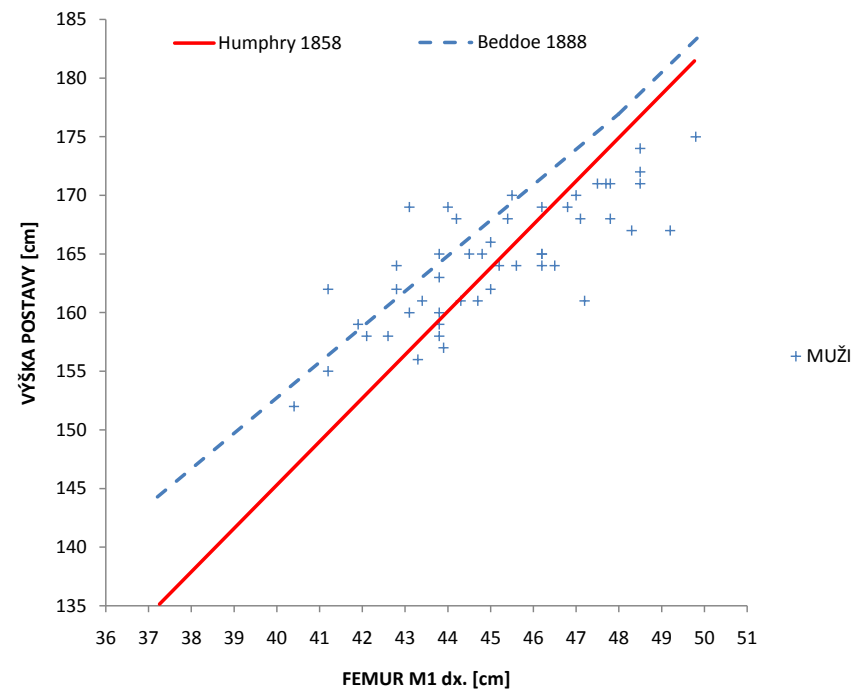

Graf I: Srovnání Humphryho (1858) a Beddoeho (1888) metody. Křivky reprezentují odhady výšky postavy z délky stehenní kosti (M1) pořízené těmito metodami. Modré křížky jsou hodnoty mužů z Rolletova (1888) souboru. Humphryho odhad lze znázornit přímkou, Beddoeho dvěma polopřímkami s počátečním bodem $[48,177]$. Vidíme, že Humphryho metoda výrazně podhodnocuje výšku postavy osob s krátkými stehenními kostmi a nadhodnocuje výšku postavy osob s dlouhými stehenními kostmi. Beddoe tento jev zčásti potlačil zavedením absolutního členu do rovnice, takže jeho přímka lépe vystihuje trend v datech. Rolletovými daty ovšem neprochází vhodně. Je posunuta př́liš nahoru a většina odhadů je tak nadhodnocena.

poměrně rychle v zapomnění. Oba využili pro tvorbu svých metod Rolletův soubor, každý ovšem volil zcela jiný př́stup.

\section{BOD ZLOMU}

První zveřejnil svou metodu Manouvrier (1893), jehož cílem bylo modifikovat Rolletovu metodu odstraněním nevynucených chyb, které vznikly jako důsledek nevhodného matematického zpracování dat. Nejprve odstranil z referenčního sou- 
boru jedince starší šedesáti let, aby eliminoval vliv zmenšování výšky postavy ve stáríi. Zpochybnil výsledky autorů, kteří řadí jedince do skupin podle výšky postavy, nebot' „(...) ont-ils pensé que, si à une taille moyenne de $1^{m}, 52$ correspondait une longueur fémorale moyenne de 415 millimètres, il s'ensuivait que, réciproquement, à une longueur fémorale moyenne 415 devait correspondre une taille moyenne de $1^{m}, 52$. (...), mais la réciprocité en question n'existe pas en réalité ${ }^{17}$ (Manouvrier 1893, s. 360)." Namísto toho seřadil jedince podle délky dlouhých kostí. Díky tomu mohl zachytit regresi k průměru. Stejně jako Beddoe (1888), i Manouvrier (1893, s. 360-361) ji vysvětluje biologicky. Definuje „macroskèles“ jako jedince $s$ relativně dlouhými končetinami vůči výšce postavy a „microskèles“ jako jedince s končetinami relativně krátkými. Přitom „macroskèles“ byli nejvíce zastoupení mezi lidmi s absolutně dlouhými končetinami, zatímco „microskèles“ mezi lidmi s končetinami absolutně krátkými. Manouvrier (1893) si přál, aby přepočtový koeficient $c_{B}$ odrážel relativní zastoupení „macroskèles" a „microskèles" pro libovolné $x_{B}$. Pro tyto účely rozdělil Rolletův soubor do tří skupin podle délky př́slušné dlouhé kosti $\left(X_{B}\right)$. Největší četnost „microskèles“ mezi jedinci s krátkými kostmi znamenala nejvyšší hodnotu přepočtového koeficientu $\left(c_{B 1}\right)$ pro tuto skupinu, střední hodnotu $\left(c_{B 2}=\bar{c}_{B}\right)$ měla skupina druhá a nejnižší hodnotu $\left(c_{B 3}\right)$ skupina s dlouhými kostmi a největší četností „macroskèles“. Interpolací $c_{B 1}, c_{B 2}$ a $c_{B 3}$ poté dopočítal koeficienty pro zvolené délky dlouhých kostí $x_{B}$. Z nich dostal vynásobením odhad výšky postavy, kterou pro odpovídající $x_{B}$ zaznamenal do tabulky. Nakonec Manouvrier (1893) navrhl systém korekcí, které měly odstranit některé metodické nesrovnalosti spojené s Rolletovými daty (1888). Celý postup odhadu výšky postavy z délky dlouhé kosti měl podle Manouvriera (1893, s. 394-396) vypadat tak, že po změření suché dlouhé kosti připočte antropolog $\mathrm{k}$ zjištěnému rozměru 2 milimetry, jelikož Rollet měřil kosti čerstvé. Následně odečte z tabulek odhad výšky. Pokud je dlouhých kostí jednoho člověka $\mathrm{k}$ dispozici více, odhady pořízené jejich prostřednictvím se zprůměrují. Od takto získaného odhadu následně odečteme $2 \mathrm{~cm}$, nebot’ o tolik byla pitvaná těla v průměru delší, než průměrná výška postavy v tehdejší Francii. Svou metodu Manouvrier také zpětně otestoval na Rolletových datech a pravděpodobně jako první vyčíslil její spolehlivost pomocí rozdílů mezi odhadem výšky postavy a její skutečnou hodnotou. Prưměrná chyba, tj. průměr absolutních hodnot těchto rozdílů, jeho metody se pohybovala v rozmezí $2,7 \mathrm{~cm}$ až $3,3 \mathrm{~cm}$ podle použité dlouhé kosti. Nutno ještě dodat, že Manouvrier neuvádí tabulky pro levou a pravou stranu zvlášt, jeho tabulka vznikla zprůměrováním délek pravé a levé strany u příslušných dlouhých kostí.

Pro srovnání s ostatními metodami jsme se pokusili vyjádřit Manouvrierovy tabulky (1893, s. 403-405) rovnicí. Manou-

17 (...) se domnívají, že pokud průměrná výška 1,52 m koresponduje s průměrnou délkou femuru $415 \mathrm{~mm}$, vyplývá z toho, že naopak průměrná délka femuru $415 \mathrm{~mm}$ musí nutně odpovídat průměrné výšce $1,52 \mathrm{~m}(\ldots)$ ale tato reciprocita ve skutečnosti reálně neexistuje. vrier přesně neuvádí, jakým způsobem koeficienty $c_{B 1}, c_{B 2}$ a $c_{B 3}$ interpoloval, předpokládejme však, že závislost přepočtového koeficientu $(c)$ na délce př́slušné dlouhé kosti $\left(x_{B}\right)$ je lineární, tj. je možné znázornit ji přímkou popsanou rovnicí

$$
c=\bar{c}_{B}+k_{B}\left(x_{B}-\bar{x}_{B}\right) \text {. }
$$

Potom lze odhad výšky postavy vyjádřit jako

$\hat{y}=c x=\left(\bar{c}_{B}+k_{B}\left(x_{B}-\bar{x}_{B}\right)\right) x_{B}=\left(\bar{c}_{B}-k_{B} \bar{x}_{B}\right) x_{B}+k_{B} x_{B}^{2}$,

což je kvadratická rovnice bez absolutního členu. Z Manouvrierovy tabulky I (1893, s. 403) jsme metodou nejmenších čtverců spočetli směrnice $k_{B}$, pro odpovídající dlouhé kosti. Např́klad pro délku kosti holenní (M1) jsme pro muže dostali směrnici $k_{T}=-0,0073$ a průměrnou hodnotu přepočtového koeficientu $\bar{c}_{T}=4,54$. Toho využijeme a pro délku tibie $\left(x_{T}\right)$ dostaneme rovnici

$$
\hat{y}=7,226 x_{T}-0,0073 x_{T}^{2}
$$

pro $x$ a $y$ v milimetrech. Zahrneme-li do rovnice i výše uvedené korekce, které Manouvrier navrhl, dostáváme rovnici

$$
\hat{y}=-5,56+7,24 x_{T}-0,0073 x_{T}^{2}
$$

pro $x_{T}$ a $y \mathrm{v}$ milimetrech. Nutno dodat, že takto získané odhady výšky postavy nekorespondují plně s údaji v Manouvrierově tabulce II a III ${ }^{18}$, což lze patrně přičíst na vrub zaokrouhlování, které při výpočtech Manouvrier prováděl, a v menší míře odlišnému způsobu interpolace koeficientů $c_{B 1}, c_{B 2}$ a $c_{B 3}$. Tyto rozdíly se ovšem pro konkrétní odhady výšky pohybují v řádu milimetrů.

Jen šest let poté, co Manouvrier publikoval svou metodu, zasáhl do diskuze Pearson (1899), který nesouhlasil s Manouvrierovým matematickým řešením, a jeho kritika na sebe nenechala dlouho čekat. Odmítl používání poměru výšky postavy $\mathrm{k}$ délce dlouhé kosti a namísto toho prosazoval lineární regresi. Definujeme-li $\hat{y}=a x+b$ jako odhad pořízený regresní rovnicí, potom regresní přímka je konstruována tak, aby reziduální součet čtverců (viz graf II)

$$
\mathrm{RSS}=\sum_{\mathrm{i}=1}^{\mathrm{n}}\left(y_{i}-\hat{\mathrm{y}}_{i}\right)^{2}=\sum_{\mathrm{i}=1}^{\mathrm{n}}\left(y_{i}-a x_{i}-b\right)^{2}
$$

byl nejmenší možný.

Je tedy třeba najít takové $a$ a $b$, pro něž je funkce RSS nejnižší. Jedná se tedy o minimum této funkce, kterého nabývá v bodě $\left[a_{\text {min }}, b_{\text {min }}\right]$. Z matematické analýzy je známo, že existují-li odpovídající parciální derivace, jsou v bodě $\left[a_{\min }, b_{\min }\right]$ rovny nule. Vyřešením rovnic

$$
\frac{\partial R S S}{\partial a}=0, \frac{\partial R S S}{\partial b}=0
$$

dostáváme:

$$
a_{\min }=\frac{s_{y}}{s_{x}} r_{x y}
$$

18 Uvádíme je rovněž jako tabulku II a III. 


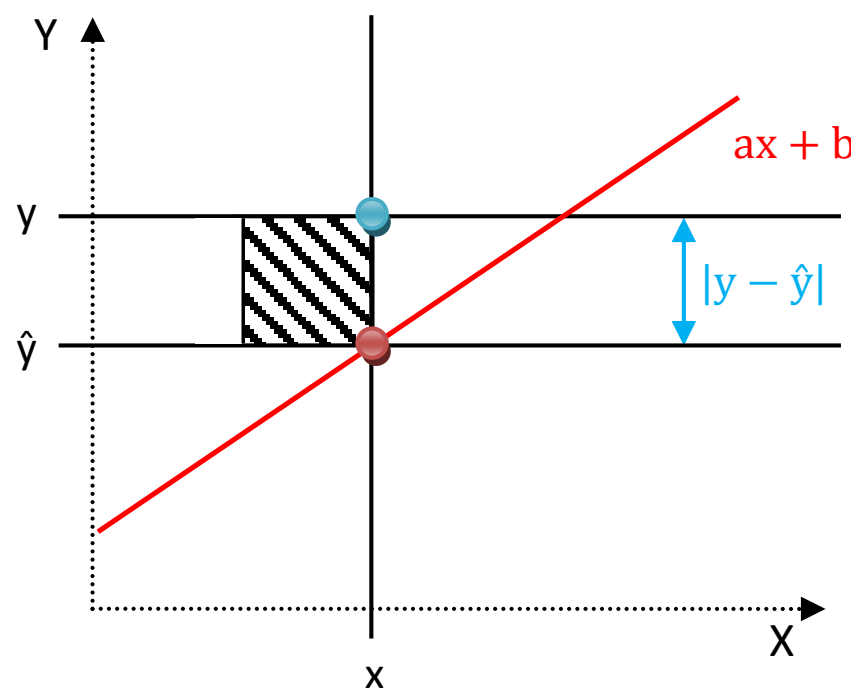

Graf II: Způsob konstrukce reziduálních čtverců (RS). Modrý bod značí souřadnici $[x, y]$, kde $\mathrm{X}$ je délka kosti a $\mathrm{Y}$ výška postavy hodnoceného jedince. Červený bod značí souřadnici $[x, \hat{y}]$, kde $\mathrm{X}$ je délka kosti a $\hat{y}$ odhad výšky založený na X.

$$
\begin{gathered}
b_{\min }=\bar{y}-\frac{s_{y}}{s_{x}} r_{x y} \bar{x} \\
\hat{\mathrm{y}}=\frac{s_{y}}{s_{x}} r_{x y} x+\left(\bar{y}-\frac{s_{y}}{s_{x}} r_{x y} \bar{x}\right),
\end{gathered}
$$

kde $s_{x}$ je výběrová směrodatná odchylka délky př́íslušné dlouhé kosti, $s_{y}$ výběrová směrodatná odchylka výšky postavy, $r_{x y}$ výběrový Pearsonův korelační koeficient mezi veličinami $X$ a $Y$ a $\bar{x}, \bar{y}$ výběrové průměry.

Dělení jedinců na „macroskèles“ a „microskèles“ považoval Pearson za zavádějící a klonil se k čistě matematické interpretaci regrese $\mathrm{k}$ průměru. Odmítl také průměrování odhadů pořizených $\mathrm{z}$ různých kostí, nebot takový postup neuvažuje korelační matici mezi výškou a délkami dlouhých kostí navzájem. Za jediný správný postup označil použití mnohonásobné regrese. Neztotožnil se s Manouvrierem ani v redukci jedinců starších šedesáti let, nebot vliv zmenšování těla považoval za zanedbatelný. Kromě základní sady regresních rovnic, které vycházely bezprostředně z Rolletových dat (1888), sestavil ještě sadu další, do níž zahrnul i korekce podobné těm, které navrhl Manouvrier (1893). Pomocí této nové sady rovnic měly být pořizovány odhady výšky postavy za života $\mathrm{z}$ délky suchých kostí. Stejně jako Manouvrier (1893), ani on neuvádí zvláštní rovnice pro strany, všechny rovnice jsou vytvořeny na základě rozměrů pravé strany těla. Nakonec porovnal odhady pořízené svou a Manouvrierovou metodou a pozoroval určité zpřesnění odhadu. Uvádí průměrnou chybu odhadu $1,6 \mathrm{~cm}$ až $2,8 \mathrm{~cm}$ podle použité rovnice. Pro srovnání (graf III) uvádíme Pearsonovy rovnice pro odhad výšky postavy mužů $\mathrm{z}$ délky kosti holenní $\left(\mathrm{M} 1, x_{T}\right)$ a maximální délky kosti stehenní (M1, $\left.x_{F}\right)$, obojí v milimetrech:

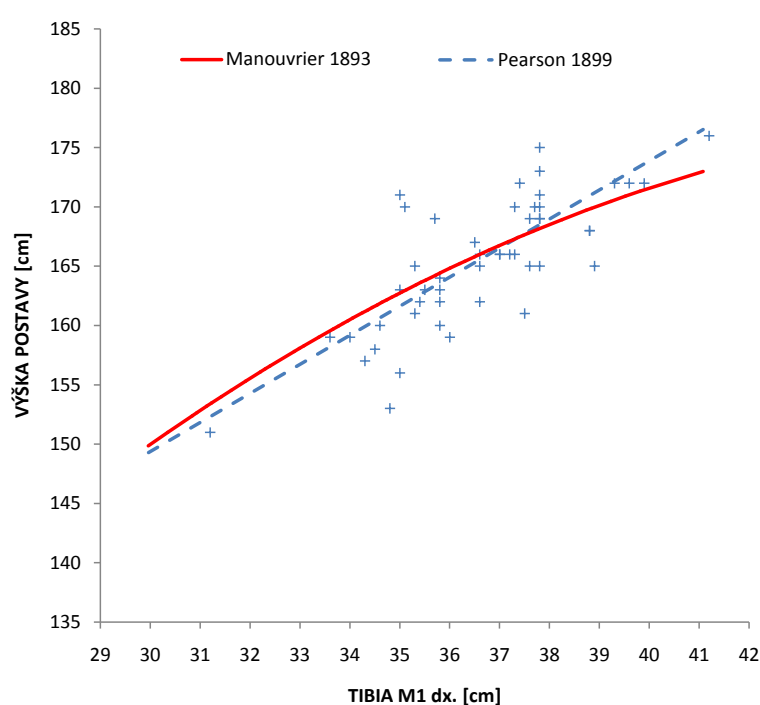

Graf III: Srovnání Manouvrierovy (1893) a Pearsonovy (1899) metody. Křivky reprezentují odhady výšky postavy mužů z délky holenní kosti (M1) Modré křížky jsou hodnoty mužů z Rolletova (1888) souboru. Obě metody byly vytvořeny na tomto souboru. Pearson využívá k odhadu regresní prímku, zatímco Manouvrier parabolu. Vidíme, že odhady se podstatně neliší, pouze pro holenní kosti delší než $40 \mathrm{~cm}$ se od sebe obě křrivky začínají více vzdalovat.

$$
\begin{aligned}
& \hat{y}=813,06+1,880 x_{F}, \\
& \hat{y}=786,64+2,376 x_{T} .
\end{aligned}
$$

\section{DOBA POVÁLEČNÁ}

Následovalo poměrně dlouhé období poznamenané dvěma světovými válkami, kdy byly využívány již ustavené metody (Rollet 1888, Manouvrier 1893, Pearson 1899) nebo vznikaly takové metody, které se od Pearsonovy (1899) odlišovaly zpravidla jen referenčním souborem a způsobem měření, nikoliv principiálně (viz tabulka IV). Během poválečné obnovy Evropy dostal Georges Fully (1926-1973), čerstvě vystudovaný lékař a pozdější generální zdravotní inspektor francouzských věznic, roku 1955 za úkol identifikovat pozůstatky deportovaných Francouzů, kteři zemřeli před osvobozením koncentračního tábora Mauthausen, ale nebyli pro nedostatek topných hmot spáleni v místních krematoriích. Jednalo se o 3165 lidí různých národností, kteří byli pohřbeni na bývalém fotbalovém hřišti jednotek Schutzstaffel (SS). Někteří $\mathrm{z}$ nich měli na zápěstí kovovou identifikační známku. Díky ukořistěným záznamům administrativy tábora, které obvykle zahrnovaly i základní antropometrické údaje, se jeho týmu povedlo tyto jedince jednoznačně identifikovat. Při identifikaci ostatních zemřelých využíval Fully zprvu Rolletových (1888) a Manouvrierových (1893) tabulek, postupně se ovšem ukazovalo, že tyto odhady nejsou pro účely identifikace jedince dost přesné. Začal tedy u skeletů proměřovat všechny kosti, které se na výšce postavy podílejí. Kosterní výška definovaná jako součet odpovídajících rozměrů těchto kostí (definice rozmě- 
rů na schématu IV) ovšem nezahrnovala tlouštku měkkých tkání ani zakřivení páteře, které výšku postavy určitou měrou ovlivňují. Tu lze vyjádřit jako

$$
y=k+a,
$$

kde $K$ je kosterní výška a $A$ ostatní faktory, které se na výšce postavy podílejí. $K$ lze změřit, $A$ odhadl Fully na základě porovnání se skutečnou výškou již identifikovaných jedinců a stanovil přepočtové konstanty

$$
\begin{aligned}
& a_{1}=10 \mathrm{~cm} \text { pro } k \leq 153,5 \mathrm{~cm}, \\
& a_{2}=10,5 \mathrm{~cm} \text { pro } 153,5<k<165,5 \mathrm{~cm} \mathrm{a} \\
& a_{3}=11,5 \mathrm{~cm} \text { pro } k \geq 165,5 .
\end{aligned}
$$

Odhadována je tedy jen poměrně malá část výšky postavy, zbytek je prostě změřen. Důsledkem je podstatně vyšší přesnost této metody oproti metodám předchozím. Fully ji ověřil na 60 identifikovaných jedincích, přičemž prưměrná chyba byla $1,28 \mathrm{~cm}$ s tím, že žádný odhad se neodchyloval od skutečnosti o více než $3,5 \mathrm{~cm}$ a odhad výšky postavy $83 \%$ jedinců se od výšky skutečné nelišil o více než $2 \mathrm{~cm}$. Navíc uvádí, že jeho metoda funguje u všech jedinců bez ohledu na etnickou prŕslušnost. Tato nesporně vysoká přesnost je však zaplacena nutností mít prakticky kompletně zachovaný skelet (resp. všechny kosti, které se na výšce postavy podílejí) a zdlouhavějším měřením, takže je relativně málo situací, kdy lze tuto anatomickou metodu reálně využít. Termín anatomická metoda poprvé použil americký anatom Thomas Dwight (1843-1911), profesor Harvard Medical School, a rozuměl pod ním všechny metody, které spočívaly v sestavení kostry jedince do anatomické polohy a jejím následném změření. On sám byl autorem jednoho $\mathrm{z}$ návodů, jak toto sestavení nejlépe provést (Dwight 1894). Tohoto postupu nevyužíval ovšem zdaleka jen Dwight, nýbrž všichni tvůrci prvních podílových metod, jmenovitě Orfila a Lesueur (1831), Humphry (1858) i Topinard (1885a). Fully (1956) sice kostry nesestavoval, jen důkladně proměřil, a sám svou metodu za anatomickou neoznačuje, toto označení se však pro jeho metodu později natolik vžilo (Raxter et al. 2006), že se dnes pod tímto pojmem rozumí právě a zejména metody tohoto typu.

Na rozdíl od Francie, kde byla užívána především Manouvrierova podílová metoda (1893), antropologové v USA preferovali Pearsonovu regresní metodu (1899). Roku 1944 rozhodl americký kongres o repatriaci amerických válečných obětí, což přineslo možnost konfrontovat jejich kosterní pozůstatky s vojenskými záznamy. Na základě těchto údajů a Terryho sbírky (Terry 1940) sestavily profesorky Mildred Trotterová (1899-1991) a Goldine Gleserová (1915-2004) z Washington University novou sadu regresních rovnic pro odhad výšky postavy z délky dlouhých kostí (Trotter, Gleser 1952). Určitým novátorstvím zde bylo přihlédnutí $\mathrm{k}$ věku jedinců a definice tzv. maximální výšky, tj. výšky jedince ve třiceti letech. Autorky (Trotter, Gleser 1951) totiž o rok dříve zjistily, že vliv věku je významným faktorem výšky postavy, přičemž celkové zmenšení těla $\mathrm{v}$ důsledku stárnutí může dosahovat až $4 \mathrm{~cm}$.
Tuto maximální výšku dopočítávají užitím lineární regrese, byt’ samy uvádějí, že závislost výšky na věku lineární není. Důležitost tohoto postupu ilustrují prŕkladem Rolletova (1888) souboru, který zahrnoval velký podíl jedinců vyššího věku, což je podle autorů jeden $z$ důvodů, proč rovnice vytvořené na tomto souboru Pearsonem (1899) podhodnocují výšku postavy amerických vojáků v průměru $06 \mathrm{~cm}$.

Postupné převládnutí regresních metod ve světě vedlo v 60 . letech 20. století i ve Franci k revizím tradičních metod. Nejprve se Fully a Pineau (1960) pokusili zobecnit původní Fullyho (1956) metodu a vytvořili sadu regresních rovnic, podle nichž šlo odhadnout délku páteře na základě výšek minimálně trojice sousedních obratlů s poměrně přijatelnou přesností, celkovou výšku postavy pak v kombinaci s délkou kosti stehenní nebo holenní. Přesnost odhadu se tím ovšem snížila. Rozsah 95\% intervalu spolehlivosti vzrostl z původních $6 \mathrm{~cm}$ na 8 až $10 \mathrm{~cm}$ podle zachovalosti skeletu. Pro porovnání, 95\% interval spolehlivosti Pearsonovy metody (1899) je široký přibližně $12 \mathrm{~cm}$. O něco později využil profesor George Olivier (1912-1996), ředitel Laboratoire d'Anthropologie de la Sorbonne ${ }^{19}$, původní Fullyho (1956) data doplněná o některé později identifikované válečné oběti k vytvoření regresních rovnic analogických těm, které uvedly pro americkou populaci dříve Trotterová a Gleserová (1952). Následně Olivier (1963) porovnal sestrojené regresní přímky s hodnotami, které uvádí ve své tabulce Manouvrier (1893). Zjistil jednak, že regresní přímky Trotterové a Gleserové (1952) mají prakticky stejné směrnice jako ty jeho, ale jsou vzhledem $\mathrm{k}$ výšce postavy posunuty přibližně o $4 \mathrm{~cm}$ výše, což Olivier (1963) interpretoval jako mezipopulační rozdíly mezi Američany a Francouzi. Naopak údaje, které uvádí Manouvrier (1893), těmto př́mkám s určitými odchylkami odpovídaly a namísto očekávaného úplného zatracení jeho metody tak došlo naopak k její rehabilitaci. Pouze pro jedince s extrémně malými (resp. velkými) délkami dlouhých kostí uváděl Manouvrier o něco menši (resp. větší) výšky postavy, než příslušné regresní rovnice. Nakonec připravil Olivier (1963) podobné tabulky jako kdysi Manouvrier, hodnoty v nich uvedené však získal prostřednictvím lineární regrese. Regresní metody poté zcela převládly nad ostatními na další tř̌i desítky let, během nichž byly spočteny stovky regresních rovnic na desítkách populací, přičemž k odhadu byly postupně použity nejrůznější kosti lidského těla.

Skutečnost, že regresní přímky dvou různých populací se mohou poměrně zásadně lišit velikostí absolutního členu (srovnej Trotter a Gleser 1952 a Olivier 1963) byla ovšem závažná, nebot znamenala nekontrolovatelné riziko systematické chyby odhadu při použití regresních rovnic na populaci o neznámých parametrech. Pokud šlo o výběr ze známé populace, bylo pro nevychýlený odhad nutné mít k dispozici regresní rovnice vytvořené speciálně pro ni. To bylo vzhledem $\mathrm{k}$ proměnlivosti populací v čase jen zřídkakdy možné zajistit. Tento stav podnítil antropology k hledání nějakého řešení. První, kdo po určitém mezidobí přišel s novou koncepcí, byl

19 Laboratoře antropologie Pařížské univerzity 


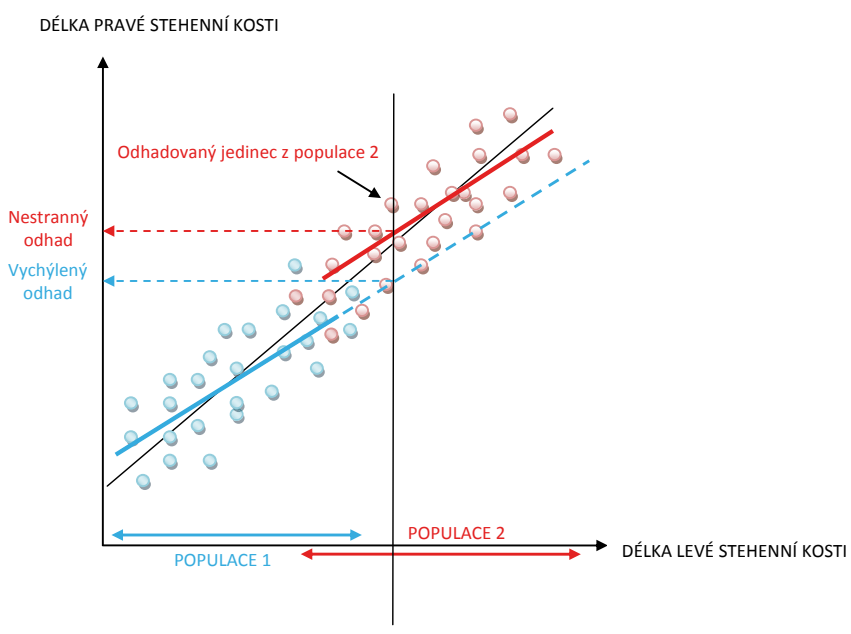

SCHÉMA II: Předpokládejme dvě populace, jejichž délka pravé stehenní kosti $D_{i}$ a délka levé stehenní kosti $G_{i}$, kde $i$ značí číslo populace, jsou normálně rozděleny se stejnými průměrnými délkami pro pravou a levou stranu $\left(E D_{1}=E G_{1}=\bar{x}_{1}, E D_{2}=E G_{2}=\bar{x}_{2}\right)$. Dále mají $D$ a $G$ obou populací stejný rozptyl $\left(D\left(D_{1}\right)=D\left(G_{1}\right)=D\left(D_{2}\right)=D\left(G_{2}\right)=s_{x}\right)$ a také oba korelační koeficienty jsou stejné $\left(R\left(D_{1}, G_{1}\right)=R\left(D_{2}, G_{2}\right)=r\right)$. Chtěli bychom odhadnout $\mathrm{z}$ délky pravé stehenní kosti délku kosti levé. Víme, že nejpřesnější nestranný odhad představuje obecně rovnice prímky

$$
\hat{\mathrm{y}}=\frac{s_{y}}{s_{x}} r x+\left(\bar{y}-\frac{s_{y}}{s_{x}} r \bar{x}\right)
$$

Rovnice odhadu pro populaci 1 bude tedy

$$
\hat{g}=\frac{s_{x}}{s_{x}} r d+\left(\bar{x}_{1}-\frac{s_{x}}{s_{x}} r \bar{x}_{1}\right)=r d+\left(\bar{x}_{1}-r \bar{x}_{1}\right)
$$

a pro populaci 2

$$
\hat{g}=\frac{s_{x}}{s_{x}} r d+\left(\bar{x}_{2}-\frac{s_{x}}{s_{x}} r \bar{x}_{2}\right)=r d+\left(\bar{x}_{2}-r \bar{x}_{2}\right) .
$$

Dokážeme, že odhady výšky postavy pořizené oběma rovnicemi nejsou stejné, pokud $r \neq 1$. Pokud by se odhady nelišily, muselo by platit

$$
\begin{aligned}
r d+\left(\bar{x}_{1}-r \bar{x}_{1}\right) & =r d+\left(\bar{x}_{2}-r \bar{x}_{2}\right) \\
\left(r \bar{x}_{1}-r \bar{x}_{2}\right) & =\left(\bar{x}_{1}-\bar{x}_{2}\right) \\
r\left(\bar{x}_{1}-\bar{x}_{2}\right) & =\left(\bar{x}_{1}-\bar{x}_{2}\right) \\
r & =1
\end{aligned}
$$

Tvrzení lze dokázat dosazením do rovnice i pro libovolné lineární transformace veličin D a G. Předpokládejme tedy, že Y lze vyjádřit jako lineární transformaci X. Platí tedy (Anděl 1986):

$$
\begin{gathered}
G=(a+b X), \quad E G=(a+b X), \quad D Y=D(a+b X)=b^{2} D D, \\
\left(\bar{y}_{1}-\frac{s_{g}}{s_{x}} r \bar{x}_{1}\right)=\left(\bar{y}_{2}-\frac{s_{g}}{s_{x}} r \bar{x}_{2}\right), \\
\left(\bar{y}_{1}-\bar{y}_{2}\right)=\frac{s_{g}}{s_{x}} r\left(\bar{x}_{1}-\bar{x}_{2}\right), \\
\left(a+b \bar{x}_{1}\right)-\left(a+b \bar{x}_{2}\right)=\frac{s_{g}}{s_{x}} r\left(\bar{x}_{1}-\bar{x}_{2}\right), \\
b=\frac{b s_{x}}{s_{x}} r \\
r=1 .
\end{gathered}
$$

Pro korelační koeficient $r \neq 1$ tedy rovnice neodhadují stejně. Patří-li jedinec do populace 2 , je pro něj ovšem nestranným odhadem regresní rovnice vytvořená na této populaci. $\mathrm{Z}$ předpokladu, že se oba korelační koeficienty rovnají a směrnice obou regresních prrímek jsou tedy stejné, plyne, že se tyto př́mky musí lišit posunutím. Důsledkem je, že regresní rovnice vytvořené na populaci jedné, nelze aplikovat na populaci druhou, pokud mají tyto populace $\mathrm{v}$ některé ze sledovaných veličin odlišný průměr, rozptyl nebo korelaci. Regresní rovnice totiž v tomto prípadě již neposkytují nestranné odhady. Výjimkou je pouze př́pad, kdy jsou korelační koeficienty $\mathrm{v}$ obou populacích rovny jedné

$$
\left(R\left(D_{1}, G_{1}\right)=R\left(D_{2}, G_{2}\right)=r=1\right) .
$$

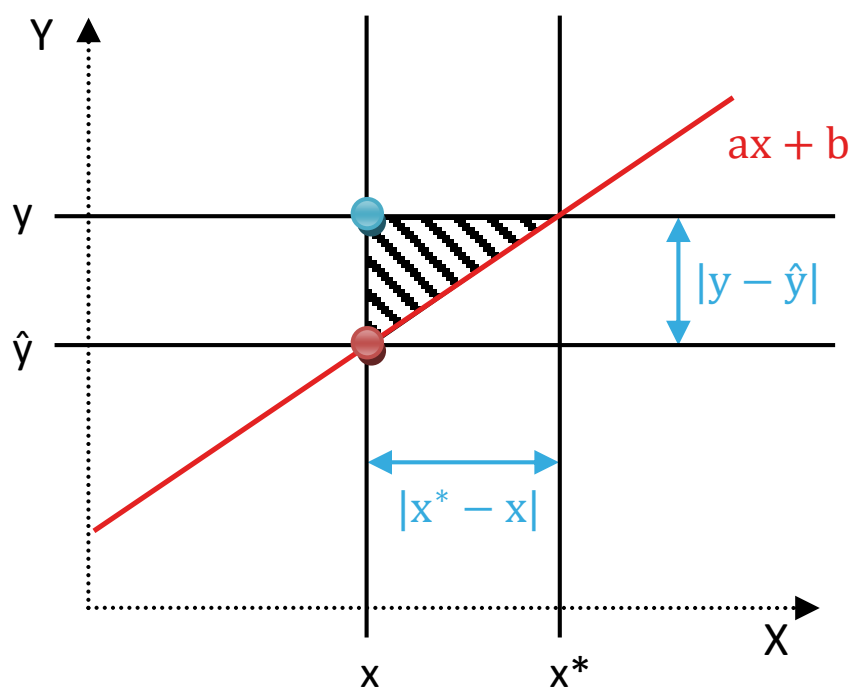

Graf IV: Způsob konstrukce reziduálních trojúhelníků (RT). Modrý bod značí souřadnici $[x, y]$, kde $\mathrm{x}$ je délka kosti a $\mathrm{Y}$ výška postavy hodnoceného jedince. Červený bod značí souřadnici $[x, \hat{y}]$, kde $\mathrm{X}$ je délka kosti a $\hat{y}$ odhad výšky založený na X.

Torstein Sjøvold $\left({ }^{\star} 1946\right)$, profesor osteologie na Stockholms universitet ${ }^{20}$. Využil přitom syntézy, kterou předtím provedl antropolog Friedrich Rösing $\left({ }^{*} 1944\right)$, profesor na Universität $\mathrm{Ulm}^{21}$, když shromáždil velké množství rovnic z dř́ve publikovaných regresních metod (Rösing 1988). Sjøvold (1990) si všiml, že regresní přímky různých populací mají obvykle téměř stejnou směrnici, liší se však posunutím. To je ovšem důsledkem metody minimalizace reziduálních čtverců, užité při jejich konstrukci, což je jediný postup, který poskytuje v rámci populace nestranné a nejpřesnějši možné odhady. Užijeme-li ovšem tuto regresní prímku pro odhad výšky postavy jedinců pocházejících z populace $s$ rozdílnou průmèrnou délkou př́islušné dlouhé kosti, budou tyto odhady zákonitě systematicky vychýleny, jak je ilustrováno ve schématu II. Tyto rozdíly mohou být zcela fatální. Duyar a Pelin (2010) odhadovali výšku 127 živých lidí žijících v turecké Ankaře z délek jejich loketních kostí. Využili prìtom 15 různých regresních rovnic vytvořených na 14 různých populacích. Jediné dvě rovnice, jejichž průměrné hodnoty odhadu výšky postavy se statisticky významně nelišily od průměrné hodnoty skutečné výšky postavy, byly obě vytvořeny na turecké populaci. Nejhủre dopadla rovnice vytvořená pro Jihoafričany, která podhodnocovala skutečnou výšku postavy v průměru o $20,71 \mathrm{~cm}$. Největší síla regresních metod, tedy zohlednění regrese $\mathrm{k}$ průměru, se ukázala být zároveň jejich největší slabinou.

Sjøvold (1990) tedy namísto regresní přímky sestrojil přim$k u$ organické korelace $^{22}$. Ta nezohledňuje regresi k průměru, ale představuje stále nejpřesnější možný takový odhad. To je dáno požadavkem na minimalizaci součtu ploch reziduálních

20 Stockholmská univerzita

21 Ulmská univerzita

22 Viz rámeček I 
trojúhelníků (RST, viz graf IV):

$R S T=\sum_{i=1}^{n}\left|y_{i}-\hat{y}_{i}\right|\left|x_{i}^{*}-x_{i}\right| / 2=\sum_{i=1}^{n}\left|y_{i}-a x_{i}-b\right|\left|\frac{\left(y_{i}-b\right)}{a}-x_{i}\right| / 2=\frac{1}{2|a|} \sum_{i=1}^{n}\left(y_{i}-a x_{i}-b\right)^{2}$

Podobně jako v př́padě minimalizace nejmenších čtverců, je i zde potřeba nalézt minimum $\left[a_{\min }, b_{\min }\right]$ funkce RST. Vyřešením rovnic

$$
\frac{\partial R S T}{\partial a}=0, \frac{\partial R S T}{\partial b}=0
$$

dostáváme:

$$
\begin{gathered}
a_{\min }=\frac{\sigma_{y}}{\sigma_{x}{ }^{\prime}} \\
b_{\min }=\bar{y}-\frac{s_{y}}{s_{x}} \bar{x} \\
\hat{\mathrm{y}}=\frac{s_{y}}{s_{x}} x+\left(\bar{y}-\frac{s_{y}}{s_{x}} \bar{x}\right) .
\end{gathered}
$$

\section{ORGANICKÁ KORELACE}

Termín organická korelace (anglicky organic correlation, doslovně by se spojení dalo přeložit jako souvztažnost orgánů) se běžně uživá již nejméně století (např. Parker 1909). Má poukazovat na skutečnost, že v živém organismu často se změnou jednoho orgánu dochází nepř́mo i ke změně orgánu jiného. Jako nástroj měření síly a směru této závislosti se záhy ujal Pearsonův korelační koeficient. Brzy poté, co jej Pearson (1896) zavedl, prakticky nahradil původní korelační koeficient Galtonův (1888), založený na mediánu jako střední hodnotě a vzdálenosti obou kvartilů jako míře rozptýlenosti. Hledání přímky, která by vhodně popisovala průběh této závislosti, však probíhalo podstatně déle. Regresní prímka nemohla být takovým nástrojem, jelikož závisí na velikosti Pearsonova korelačního koeficientu a na volbě nezávislé a závislé proměnné. Pearson (1901) proto navrhl využívat k tomuto účelu hlavní osu (anglicky major axis) elipsoidu vícerozměrného normálního rozdělení a nazval ji „line of best fit“ (tedy nejvhodnějši prímkou). Jones (1937) však ukázal, že s rostoucím rozptylem jedné $\mathrm{z}$ měřených veličin konverguje hlavní osa elipsoidu k regresní prrímce odvozené od dané veličiny coby nezávislé proměnné. $\mathrm{V}$ důsledku toho získáme napríklad pro popis vztahu mezi hmotností a výškou postavy s použitím různých jednotek (např. metrů a centimetrů u výšky postavy) různé přímky s různými směrnicemi. Tyto směrnice na sebe přitom nejsou navzájem převoditelné užitím převodních vztahů (např. $1 \mathrm{~m}=100 \mathrm{~cm}$ ). Hlavní osa elipsoidu není tedy pro popis vztahu orgánů univerzální prostředek a navíc opět závisí na korelačním koeficientu. Jones $(1937$, s. 28) dokonce píše, že termín „line of best fit“ je pro tuto př́ímku zavádějící, nebot může podle okolností ležet kdekoliv v prostoru vymezeném sdruženými regresními př́mkami. Roos (1937) ukázal, že všechny přímky, které prokládají elipsoid dvourozměrného normální rozdělení na základě minimalizace reziduálního rozptylu, se dají vyjádřit jedinou rovnicí

$$
\left(\sigma_{x} \sigma_{y} \rho_{x y}-k \sigma_{x}^{2}\right) y=\left(\sigma_{y}^{2}-k \sigma_{x} \sigma_{y} \rho_{x y}\right) x,
$$

kde $\mathrm{x}, \mathrm{y}$ jsou realizacemi centrovaných náhodných veličin $\mathrm{X}$ a $\mathrm{Y}, \rho_{x y}$ je Pearsonův korelační koeficient mezi veličinami $\mathrm{X}$ a $\mathrm{Y}, \sigma_{x}$ a $\sigma_{y}$ jsou př́slušné směrodatné odchylky a $k=\tan \alpha$, kde $\alpha$ je úhel s osou $\mathrm{x}$, pod nímž měříme rozptyl reziduí. Jinými slovy, směrnice $k$ určuje, jaký podíl rozptylu nevysvětleného konstruovanou prímkou přiííšeme oběma veličinám. Například pro $\alpha=90^{\circ}$ počítáme reziduální rozptyl souběžně s osou y a dostáváme regresní př́mku s proměnnou $\mathrm{x}$ jako nezávislou proměnnou. Další význačnou hodnotou je $\alpha=45^{\circ}, \mathrm{kdy}$ přisuzujeme stejný podíl na rozptylu reziduí oběma veličinám. Jones (1937) poukázal na speciální př́ípad, kdy předpokládáme, že obě veličiny se na rozptylu reziduí podílejí př́mo úměrně své směrodatné odchylce $s_{x}, s_{y}$.
Potom

$$
\begin{gathered}
k=-\operatorname{sgn}(\rho) \frac{\sigma_{y}}{\sigma_{x}} \\
y=\frac{\sigma_{y}}{\sigma_{x}} x .
\end{gathered}
$$

Tato př́mka byla později označována jako redukovaná hlavní osa (anglicky reduced major axis) a někteř́ autoři ji začali užívat pro popis průběhu závislosti namísto hlavni osy (Teissier 1948; Kermack, Haldane 1950). Termíny redukovaná hlavní osa a přimka organické korelace $\mathrm{v}$ průběhu dalších let postupně splynuly a jsou někdy zaměňovány (Sjøvold 1990), přestože jsou $\mathrm{z}$ definic totožné pouze za výše uvedeného předpokladu.

Rámeček I: Historie organické korelace.

Přímka organické korelace je tedy totožná s prrímkou regresní, pokud $r_{x y}=1$. Nezohlednění regrese $\mathrm{k}$ průměru však vede ke zvýšení chyby odhadu, nicméně jen mírnému. Při hodnotě $r_{x y}=0,8$ to znamená rozšíření intervalu spolehlivosti odhadu o 5,4\% oproti lineární regresi. Navíc Sjøvold (1990) pracoval s průměrnými hodnotami ze starších studií, které shromáždil Rösing. To ještě umocňuje univerzálnost jeho metody a nikterak neškodí nestrannosti odhadu, nebot patří-li jedinci do určité populace, je mezi nimi výška postavy rovnající se populačnímu průměru zřejmě nejvíce zastoupena, tedy je pro takové jedince i nejvíce pravděpodobná.

\section{SOUČASNOST}

Sjøvoldova metoda (1990) byla sice přijata pozitivně a využívána, přišla ovšem již v době, kdy začala vzrůstat obecná nedůvěra vůči odhadům výšky postavy založeným pouze na délkách dlouhých kostí. Pearsonova lineární regrese zcela zklamala (viz Duyar, Pelin 2010) a naděje, že by se někdy mohla stát účinným nástrojem pro spolehlivý odhad, se postupně rozplynuly. Nastává renesance Fullyho anatomické metody (1956), dosud jen zřídka užívané (např. Snow, Williams 1971; Lundy 1988). Ta se nově stala prredmětem inovací a postupného zdokonalování. Raxterová et al. $(2006 ; 2007)$ podrobně revidovali Fullyho metodu (1956), doplnili definice některých rozměrů, které nebyly z Fullyho popisu chápány jako jednoznačné23 a do přepočtu kosterní výšky na výšku postavy zahrnuli vliv věku. Auerbach (2011) vyzkoušel u 2717 jedinců ze 123 pohřebišt různých kultur z celé Ameriky několik způsobů, jak odhadnout délky některých chybějících segmentů kosterní výšky ze segmentů dostupných. Zjistil, že některé je možné odhadnout poměrně přesně, zejména chyba odhadu výšky obratle na základě výšek obratlů sousedních se pohybovala na hranici chyby měření. Jediným segmentem, který v žádném př́padě nedoporučil k odhadu, je výška lebky, jelikož i při zahrnutí všech ostatních komponent kosterní výšky do regresní rovnice bylo vysvětleno jen asi $15 \%$ její variance. Vznikají i nové regresní metody, př́stup k nim se však změnil. Jejich plošné využití není považováno za správné (Duyar,

23 Do češtiny přeložené definice rozměrů jsou uvedeny ve schématu III. 


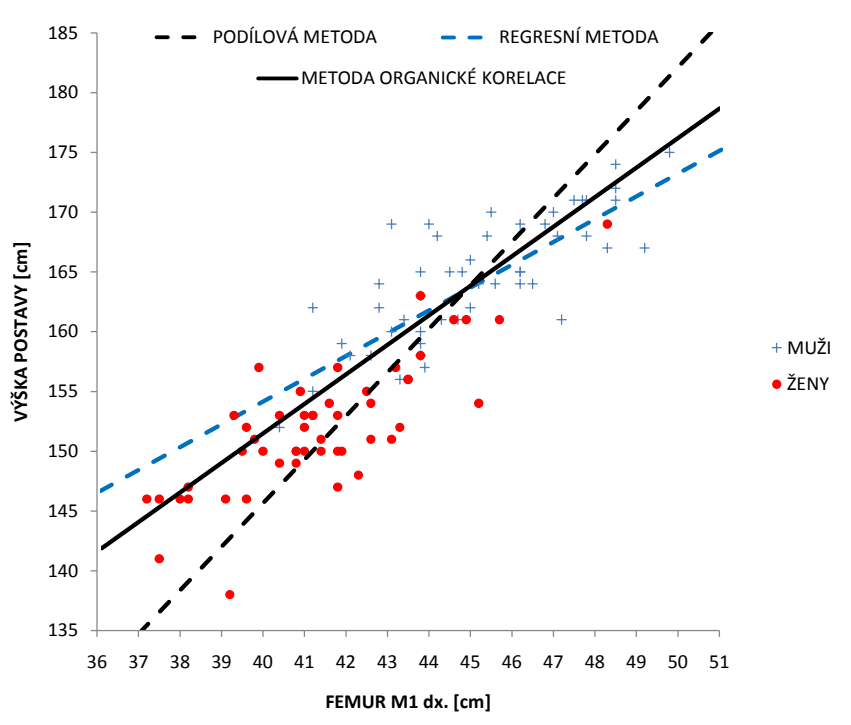

Graf V: Srovnání metody podílové, regresní a organické korelace. Př́mky reprezentují odhady výšky postavy z délky stehenní kosti (M1). Jejich rovnice jsme sestavili na základě hodnot mužủ z Rolletova souboru (1888). Ti jsou v grafu označeni modrými kř́žky, červené body představují hodnoty žen. Vidíme, že všechny přímky se protínají v jediném bodě $\left[\bar{x}_{M} \bar{y}_{M}\right]$, kde $\bar{x}_{M}$ je průměrná délka stehenní kosti a $\bar{y}_{M}$ průměrná výška postavy pro muže. Nejlépe prochází shlukem bodů mužů bezesporu regresní přímka, hodnoty žen však tato prŕmka vystihuje velice špatně a s výjimkou třech př́padů všechny nadhodnocuje. Je to dáno tím, že prímka byla vytvořena na populaci mužů $\mathrm{z}$ Francie 19. století a nelze ji bez rizika vychýlení odhadů aplikovat na populaci jinou, tedy ani na populaci francouzských žen ze stejné doby. Podílová metoda, byt matematicky méně sofistikovaná, si vede o poznání lépe, jelikož implicitně nevyžaduje shodu populací. Předpokládá pouze, že různé populace mají v průměru stejné tělesné proporce. Jde o problematický předpoklad, jehož platnost je nejistá. $V$ našem případě ovšem zřejmě platí a proto přímka prochází shlukem bodů žen stejně dobře jako shlukem bodů mužů. Jak je uvedeno výše v textu, nejedná se ovšem zdaleka o nejpřesnější možné odhady výšky postavy ani pro jednu skupinu. Přímka organické korelace velice dobře vystihuje celkový trend $\mathrm{v}$ datech bez ohledu na pohlaví. Pro muže sice nepředstavuje natolik přesný odhad jako regresní přímka, data žen prokládá ovšem výrazně lépe. Zdá se však, že shluk bodů žen je položen o něco níže, než by odpovídalo prrímce organické korelace. Je otázkou, zda jde jen o náhodnou odchylku nebo o důsledek porušení předpokladů aplikace př́mky organické korelace.

Pelin 2010), namísto toho se ujala koncepce individuálního př́stupu ke studovaným populacím. První s tímto nápadem přišli pravděpodobně Sciulli et al. (1990). Pro 64 paleoindiánů $\mathrm{z}$ území dnešního Ohia nejdříve vypočítali výšku postavy Fullyho metodou a na základě těchto odhadů sestavili sadu regresních rovnic šitou této populaci na míru. Stejným způsobem postupovali v poslední době Vercellotti et al. (2009) nebo Auerbach a Ruff (2010). Jiný př́stup zvolili Giannecchini a Moggi-Cecchi (2008), kteří se snažili vybrat nejvhodnější regresní rovnici podle tělesných proporcí. Pro každou z posuzovaných metod vypočetli rozdíly mezi odhady výšky postavy pořízenými na základě délek různých dlouhých kostí a jako nejlepší vybrali tu metodu, která měla tento rozdíl v průměru nejnižší. To mělo zaručit, že použité regresní rovnice byly vytvořeny na populaci, která je svou proporcionalitou nejbližší studovanému souboru. Autoři ovšem nijak nedokázali, že stejné proporce znamenají nutně nejnižší hodnotu rozdílů v odhadu a naopak ani to, že tyto nejnižší rozdíly v odhadu odpovídají vždy nejmenším rozdílům v proporcích.

\section{SITUACE V ČECHÁCH A NA MORAVĚ}

V roce 1912 byly na mezinárodním antropologickém kongresu v Ženevě schváleny jako norma pro odhad výšky postavy Manouvrierovy tabulky (1893). Ustanovení bylo součástí tehdejší snahy o sjednocení antropologických měr a metod (Suchý 1967, s. 161). Čeští a moravští antropologové se doporučením dlouho řídili. Suchý $(1967$, s. 161) označuje ještě v roce 1967 Manouvrierovu poměrovou metodu za obecně užívanou metodu pro odhad výšky postavy. Uvádí sice i další metody (Breitinger 1937; Telkkä 1950; Trotter, Gleser 1952), dodává však: „Úvaha, že jejich použití je vhodnější jen proto, že jsou to metody nové, je pro naše území problematická; byly totiž odvozeny z výzkumů obyvatelstva, které pochází z jiných oblastí." Suchého názor chápeme tak, že zmiňované nové metody byly stejně jako ta Manouvrierova vytvořeny na odlišných populacích, než je populace česká, a není proto zásadní důvod $\mathrm{k}$ nim přecházet. Nepř́mo také poukazuje na absenci jakékoliv metody vytvořené přímo na české populaci. Doba, kdy byla Manouvrierova metoda považována za normu, se přesto již chýlila ke konci. Na její místo se prosadily metody Breitingera (1937) a Bacha (1965) ${ }^{24}$, snad pro geografickou a kulturní blízkost německého prostředí. Přechod od Manouvrierovy poměrové metody (1893) k Breitingerově (1937) a Bachově (1965) regresní metodě u nás proběhl někdy v 70. a 80. letech 20. století. Stloukal a Vyhnánek (1976) z Národního muzea v Praze sice odhadovali výšku Slovanů z Mikulčic jen za pomoci Manouvrierových tabulek, nicméně o metodách Breitingera a Bacha se vyjadřují kladně. Vysvětlují, že Manouvrierovu metodu užili proto, že v době, kdy Bach (1965) publikoval rovnice pro ženy, měli svůj soubor již zčásti zpracován. Lorencová et al. (1987) z University J. E. Purkyně v Brně (dnes Masarykova univerzita) použili pro určení odhadu výšky skeletů z pohřebiště kultury s lineární keramikou v Těšeticích-Kyjovicích jak Manouvrierovu metodu, tak metody Breitingera a Bacha. Ve stejné době publikovali Černý a Komenda (1982) první metodu pro odhad výšky vytvořenou na české populaci, později $k$ ní přibyla ještě metoda Dobisíkové et al. (2000). Navzdory tomu u nás ani jedna z nich nepřevládla a nadále se standardně užívaly metody Breitingera a Bacha. Zdá se, že v 90. letech se začala situace měnit. Zatímco někteří antropologové nadále preferují regresní metody Breitingera a Bacha (např. Dobisíková et al. 2008; Dobisíková 2009), jiní přešli na Sjøvoldovu metodu (1990) organické

24 Breitinger (1937) vytvořil sadu regresních rovnic na základě měření účastníků atletického klání v Mnichově roku 1923 (1 400 mužů) a studentů z Mnichova v roce 1925-1926 (1 000 mužů). Bach (1965) přidal později ještě regresní rovnice pro ženy sestavené na základě měření studentek z Jeny (500 žen). Metody jsou v Evropě oblíbené pro značné vzorky, na jejichž základě byly vytvořeny, a jsou obvykle užívány dohromady jako jedna metoda. 


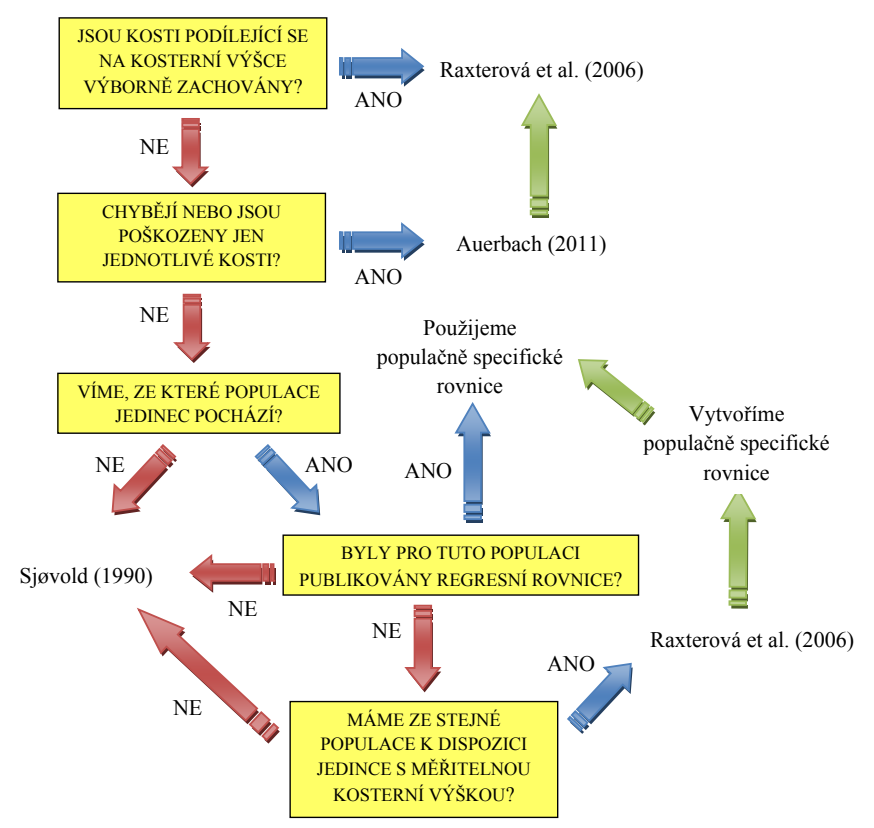

Schéma III: Doporučený postup při výběru metody pro odhad výšky postavy podle skeletu v závislosti na kompletnosti skeletu a dostupnosti populačně specifických rovnic. Nejprve zjistíme, zda je skelet dostatečně zachovalý pro použití anatomické metody. Pokud ano, použijeme dosud nejpřesnější metodu Raxterové et al. (2006). Pokud některé kosti chybí, ale je možné chybějící segmenty odhadnout podle přítomných, odhadneme chybějící segmenty metodou Auerbacha (2011) a na kompletní sadu rozměrů opět aplikujeme metodu podle Raxterové et al. (2006). Je-li však skelet značně nekompletní, přistoupíme $\mathrm{k}$ metodám založeným na odhadech $\mathrm{z}$ jednotlivých kostí a jejich kombinací. Pokud neznáme populaci, z níž jedinec pocházel, použijeme Sjøvoldovu (1990) metodu organické korelace. Pokud populaci známe a máme $\mathrm{k}$ dispozici populačně specifické regresní rovnice, využijeme pro odhad jich, přičemž upřednostníme tu nejpřesnější (většinou kombinace několika kostí). Pokud populaci hodnoceného skeletu známe, ale regresní rovnice pro ni specifické nejsou dostupné, můžeme postupovat následujícím způsobem. Použijeme jiné kompletní skelety $\mathrm{z}$ téže populace, odhadneme pomocí anatomické metody Raxterové et al. (2006) jejich výšku postavy a z takto získaných dat vytvoříme vlastní regresní rovnice pro kosti, které máme $\mathrm{k}$ dispozici u hodnoceného skeletu. Ty pak použijeme $\mathrm{k}$ odhadu výšky postavy u tohoto skeletu. $V$ opačném př́padě, tj. když sice populaci známe, ale specifické rovnice dostupné nejsou a nové nelze vytvořit, použijeme opět Sjøvoldovu (1990) metodu organické korelace.

korelace (např. Drozdová 2005; Fojtová et al. 2008), popřípadě využívají metody obě. Například Živný (2010) z Ostravské univerzity odhadoval výšku postavy u středověké populace ze hřbitova u kostela sv. Jakuba v Brně podle Sjøvolda (1990), Breitingera (1937) a Bacha (1965) i Černého a Komendy (1982) současně.

\section{ZÁVĚR}

V historickém přehledu byly objasněny výhody a nevýhody čtyř skupin metod pro odhad výšky postavy ze skeletu. Jedná se o metody podílové, regresní, anatomické a metody organické korelace.

Metody podílové jsou významné především rolí, kterou v dějinách odhadování výšky postavy ze skeletu sehrály. Doporu-

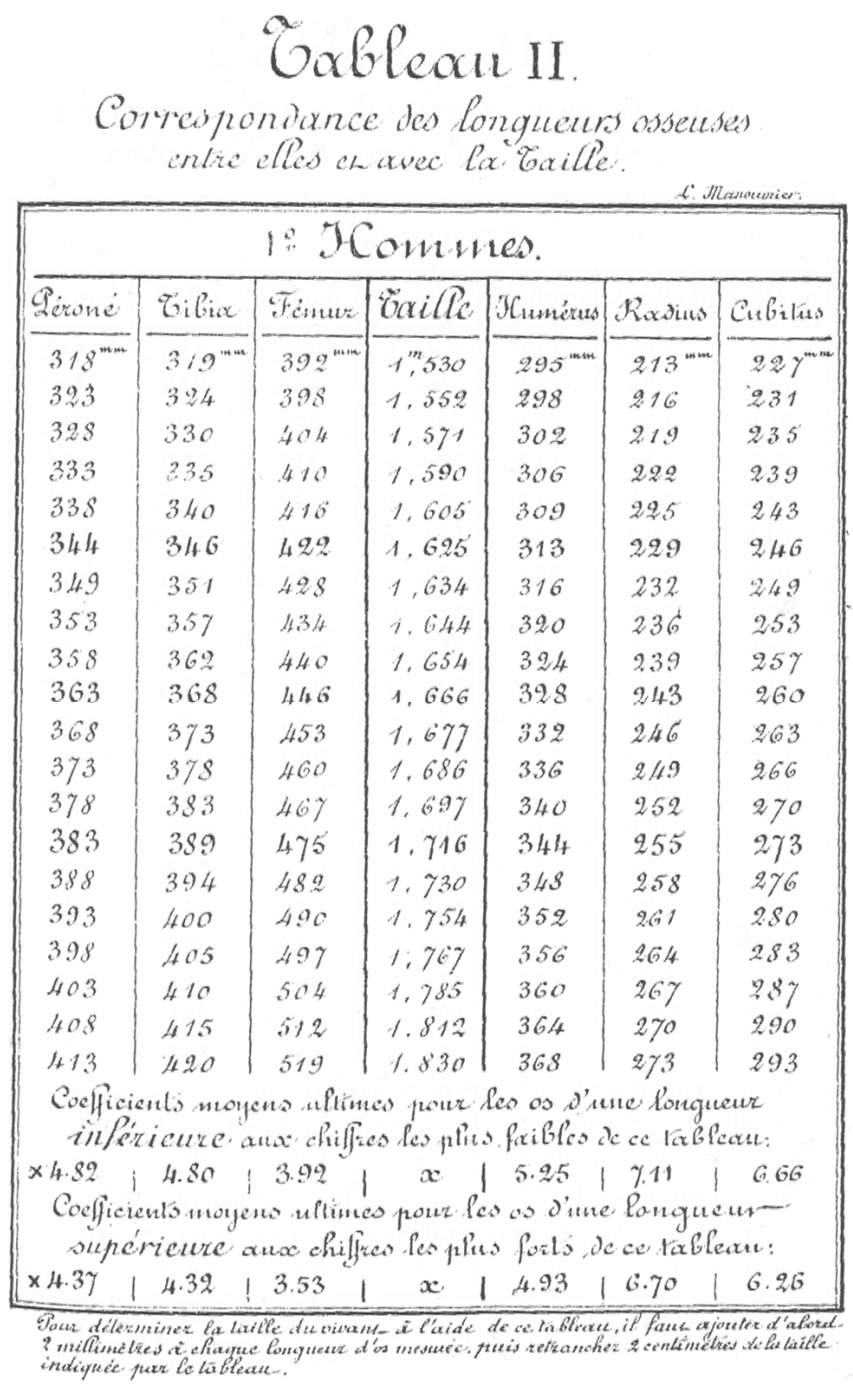

Tabulka II: Manouvrierova (1893) tabulka pro odhad výšky postavy (Taille) mužů $z$ délky následujících dlouhých kostí: fibula (Peroné), tibia, femur (Fémur), humerus (Humérus), radius, ulna (Cubitus).

čit je však na základě studia jejich matematických vlastností nelze, protože jsou dnes k dispozici metody, u nichž je při splnění určitých předpokladů zaručena nestrannost a nejvyšší možná přesnost. Nutno ovšem zdůraznit, že Manouvrierova metoda byla až do 70 . let 20. století v Čechách a na Moravě uživána prakticky výhradně a byla za tuto dobu aplikována na bezpočet kosterních pozůstatků, či jejich souborů.

Regresní metody prokládají přímku daty tak, aby reziduální součet čtverců byl minimální. Proto poskytují nejpřesnější možný nestranný odhad výšky postavy. Nutnou podmínkou je ovšem příslušnost posuzovaných osob k populaci, pro niž byla metoda vytvořena. Pokud je tento předpoklad porušen, mohou být odhady systematicky vychýleny až o desítky centimetrů. Tyto metody lze proto doporučit tehdy, pokud víme, $\mathrm{z}$ jaké populace náš vzorek pochází, a máme $\mathrm{k}$ dispozici potřebné regresní rovnice. Pro současnou českou populaci doporučujeme metodu Dobisíkové et al. (2000). Pro populace jiné lze metodu vybrat $\mathrm{z}$ tabulky IV. 


\section{Toableau III \\ Correspondance des Pongueurs ossoused entre clles en ave ba Gaxile}

\begin{tabular}{|c|c|c|c|c|c|c|}
\hline \multicolumn{7}{|c|}{ Temmes. } \\
\hline Séroné & Gibia & Fenur & Goulle & Thunérus & Radius & Cubitio \\
\hline 283 & $2 S 4$ & 363 & $1^{m}, 400$ & 263 & 193 & 203 \\
\hline $2 \mathcal{B}$ & 289 & 368 & 1,420 & 266 & 195 & 206 \\
\hline 293 & 294 & 373 & 1. Hito & 270 & 197 & 209 \\
\hline 298 & 299 & 378 & 1,455 & 293 & 199 & 212 \\
\hline 303 & 304 & 383 & 1,470 & 276 & 201 & 215 \\
\hline 307 & 309 & $38 s$ & $1,48 s$ & 279 & 203 & 217 \\
\hline 311 & 314 & 393 & 1,497 & 282 & 205 & 219 \\
\hline 316 & 319 & 398 & 1,513 & 285 & $20 \%$ & 222 \\
\hline 320 & 324 & 1103 & 1,528 & 289 & 209 & 225 \\
\hline 325 & 329 & 408 & 1,543 & 292 & 211 & 228 \\
\hline 330 & 334 & 415 & 1.556 & 297 & 214 & 231 \\
\hline 336 & 340 & 492 & 1.568 & 309 & 218 & 235 \\
\hline 3441 & 346 & 429 & $1,5 \mathcal{S} 2$ & 307 & 222 & 239 \\
\hline 346 & 352 & 436 & 1.595 & 343 & 226 & 243 \\
\hline 351 & 358 & 443 & 1.612 & 318 & 230 & 247 \\
\hline 356 & 364 & 450 & 1.630 & $32 / 4$ & 234 & 251 \\
\hline 361 & 370 & 457 & 1.650 & 329 & 2.38 & 254 \\
\hline 366 & 376 & 464 & 1.670 & 334 & 242 & 258 \\
\hline 371 & 382 & 471 & 1,692 & 339 & 240 & 261 \\
\hline 376 & 388 & $|47 \mathcal{S}|$ & $|1.715|$ & 344 & 250 & 264 \\
\hline \multicolumn{7}{|c|}{ 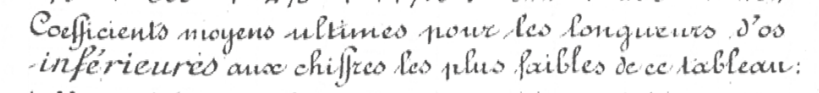 } \\
\hline \multicolumn{7}{|c|}{ 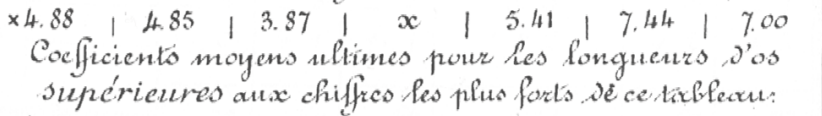 } \\
\hline$\times 4.521$ & 4.42 & $\mid 3.58$ & $x \mid$ & $4.98 \cdot 1$ & 7.00 & 6.49 \\
\hline
\end{tabular}

Tabulka III: Manouvrierova (1893) tabulka pro odhad výšky postavy (Taille) žen z délky následujících dlouhých kostí: Fibula (Peroné), Tibia, Femur (Fémur), Humerus (Humérus), Radius, Ulna (Cubitus).

Metody organické korelace prokládají prímku daty tak, aby součet ploch reziduálních trojúhelníkủ byl minimální. Odhad není obecně nejpřesnější možný a je vždy méně přesný, než odhad pořízený oprávněně použitou regresní metodou. Je ovšem nestranný, a to i tehdy, pochází-li posuzované osoby z populace odlišné od té, na níž byla metoda vytvořena. Není tedy nutné znát populační př́islušnost posuzovaných osob. Metodu lze doporučit $\mathrm{v}$ př́ípadě, že neznáme populaci, z níž náš vzorek pochází. Pro tyto účely doporučujeme Sjøvoldovu metodu (1990), jejíž výhodou je i to, že nevznikla na základě pozorování jediné populace, nýbrž na základě metaanalýzy řady populací $z$ celého světa.

Anatomické metody jsou mezním př́ípadem metod předchozích, kdy máme $\mathrm{k}$ dispozici všechny nebo téměř všechny nezbytné kosti od lebky po kost patní. Odhadnout potom zbývá jen poměrně malou část výšky postavy. Chyba odhadu je v důsledku toho tak nízká, že rozdíly v odhadu pořízeném lineární regresí, podílovou metodou či organickou korelací

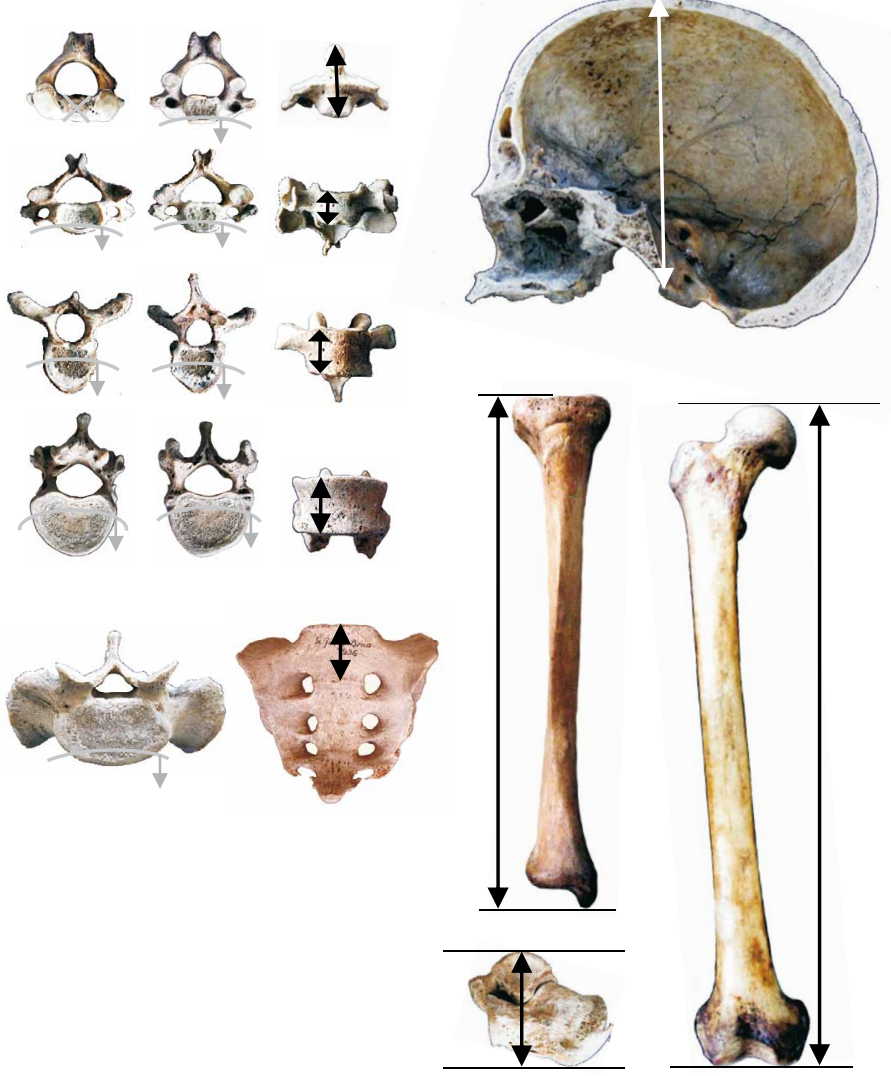

Schéma IV: Definice rozměrů pro výpočet kosterní výšky spolu s jejich schematických vyjádřením. Rozměry přeloženy podle Raxterové et al. (2006). Šedými liniemi (šedým kř́žkem) a šedými šipkami jsou znázorněny oblasti, $\mathrm{v}$ nichž se měří, dvojité šipky udávají samotný rozměr.

Lebka: Maximální vzdálenost mezi body bregma a basion (M17). Dotykové měřidlo.

Axis C2: Vzdálenost nejvyššího bodu na dens axis od nejnižšího bodu na hraně mezi přední a dolní plochou těla obratle. Posuvné měřidlo.

Krční obratle C3-C7: Maximální výška těla obratle měřená mediálně od nahoru vybíhajících okrajů. Posuvné měřidlo.

Hrudní obratle: Maximální výška těla obratle před foveae costales a pediculi arcus vertebrae. Posuvné měřidlo.

Bederní obratle: Maximální výška těla obratle před pediculi arcus vertebrae. Nezahrnuje jakékoliv zesílení těla obratle v důsledku prŕtomnosti pediculi arcus vertebrae. Posuvné měřidlo.

První křížový obratel: Maximální výška těla obratle mezi bodem na hraně jeho přední a horní plochy a odpovídajícím bodem na linii srůstu S1 a S2 na facies pelvinae. Obvykle se nachází v mediánní rovině. Měříme rovnoběžně s přední stranou $\mathrm{S} 1$. Posuvné měřidlo.

Femur: Fyziologická délka (M2). Osteometrická deska.

Tibia: Celková délka (M1). Osteometrická deska.

Talus a Calcaneus: Spojíme levý talus a calcaneus pravou rukou (a naopak pravý talus levou rukou), nastavíme distální kloubní plochu směrem od dlaně tak, aby palec byl nad trochlea peronealis $\mathrm{v}$ místě, kde se talus a calcaneus spojují, ukazováček na mediální straně trochlea tali a prostředníček pod sustentaculum tali. Opřeme trochlea tali o pevný konec osteometrické desky, tak aby mediální i laterální okraj trochlea tali byly s deskou v kontaktu. Otáćíme s trochlea tali tak dlouho až pevný konec osteometrické desky vytvoří tečnu uprostřed laterální hrany trochlea tali. Nakonec umístíme posuvný konec osteometrické desky na nejnižší bod tuber calcanei. Osteometrická deska. Poznámka: Do žádného z rozměrů nezahrnujeme žádné artritické nebo osteofytické výrůstky. Párové kosti (femur, tibia, talus, calcaneus) změříme obě a pro výpočty použijeme jejich průměrnou hodnotu. 


\begin{tabular}{|c|c|c|c|c|c|c|c|c|c|c|}
\hline AUTOŘI & & $\begin{array}{l}\text { POČET } \\
\text { OSOB }\end{array}$ & POPULACE & PŮVOD & Místo & SPECIFIKACE VZORKU & $\begin{array}{c}\text { ZEMŘELÍ } \\
\text { OD }\end{array}$ & $\begin{array}{c}\text { ZEMŘELÍ } \\
\text { DO }\end{array}$ & POHLAVÍ & $\begin{array}{c}\text { PRŮMĚRNÝ } \\
\text { VĚK }\end{array}$ \\
\hline Pearson & 1899 & 50 & FRA & evropský & Lyon & pitvaná těla & & 1889 & M & 60 let \\
\hline Pearson & 1899 & 50 & FRA & evropský & Lyon & pitvaná těla & & 1889 & $\mathrm{~F}$ & 56 let \\
\hline Breitinger & 1937 & 2428 & DEU & evropský & Mnichov & studenti, sportovci & živí lidé & živí lidé & M & 26 let \\
\hline Telkkä & 1950 & 115 & FIN & evropský & Helsinky & pitvaná těla & & 1950 & M & 42 let \\
\hline Telkkä & 1950 & 39 & FIN & evropský & Helsinky & pitvaná těla & & 1950 & $\mathrm{~F}$ & 50 let \\
\hline Trotter, Gleser & 1952 & 545 & USA & evropský & USA & vojáci z druhé světové války & 1941 & 1945 & M & 23 let \\
\hline Trotter, Gleser & 1952 & 54 & USA & africký & USA & vojáci z druhé světové války & 1941 & 1945 & M & 25 let \\
\hline Trotter, Gleser & 1952 & 255 & USA & evropský & St. Louise & pitvaná těla z Terryho sbírky & 1889 & 1941 & M & 62 let \\
\hline Trotter, Gleser & 1952 & 360 & USA & africký & St. Louise & pitvaná těla z Terryho sbírky & 1889 & 1941 & M & 49 let \\
\hline Trotter, Gleser & 1952 & 63 & USA & evropský & St. Louise & pitvaná těla z Terryho sbírky & 1889 & 1941 & $\mathrm{~F}$ & 64 let \\
\hline Trotter, Gleser & 1952 & 117 & USA & africký & St. Louise & pitvaná těla z Terryho sbírky & 1889 & 1941 & $\mathrm{~F}$ & 47 let \\
\hline Trotter, Gleser & 1958 & 4672 & USA & evropský & USA & vojáci z Korejské války & 1950 & 1953 & M & 20 let \\
\hline Trotter, Gleser & 1958 & 577 & USA & africký & USA & vojáci z Korejské války & 1950 & 1953 & $M$ & 20 let \\
\hline Trotter, Gleser & 1958 & 92 & Hawai, USA & asijský & USA & vojáci z Korejské války & 1950 & 1953 & M & 20 let \\
\hline Trotter, Gleser & 1958 & 112 & Mexičané & evropský & USA & vojáci z Korejské války & 1950 & 1953 & M & 20 let \\
\hline Trotter, Gleser & 1958 & 64 & USA & evropský & Puerto Rico & vojáci z Korejské války & 1950 & 1953 & M & 20 let \\
\hline Allbrook & 1961 & 30 & Nilohamité & africký & Uganda & vězni & živí lidé & živí lidé & M & \\
\hline Allbrook & 1961 & 74 & Bantuové & africký & Uganda & studenti & živí lidé & živílidé & M & 22 let \\
\hline Allbrook & 1961 & 72 & Bantuové & africký & Keňa & studenti & živí lidé & živí lidé & M & 21 let \\
\hline Allbrook & 1961 & 39 & Bantuové & africký & Tanganika & studenti & živí lidé & živí lidé & M & 21 let \\
\hline Allbrook & 1961 & 200 & GBR & evropský & anglicko-welšské pomezí & vojáci & živí lidé & živí lidé & M & 20 let \\
\hline Olivier & 1963 & 136 & FRA, ITA & evropský & Mauthausen & vězni & 1938 & 1945 & $M$ & 35 let \\
\hline Bach & 1965 & 500 & DEU & evropský & Jena & studentky & živí lidé & živí lidé & $\mathrm{F}$ & 23 let \\
\hline Černý, Komenda & 1982 & 148 & CZE a DEU & evropský & Praha, Plzeň & pitvaná těla & 1933 & 1939 & M & 55 let \\
\hline Černý, Komenda & 1982 & 104 & CZE a DEU & evropský & Praha, Plzeň & pitvaná těla & 1933 & 1939 & $\mathrm{~F}$ & 53 let \\
\hline Dobisíková et al. & 2000 & 107 & CZE & evropský & Praha & pitvaná těla & & & M & 49 let \\
\hline Dobisíková et al. & 2000 & 53 & CZE & evropský & Praha & pitvaná těla & & & $\mathrm{F}$ & 55 let \\
\hline
\end{tabular}

Tabulka IV: Přehled vybraných lineárně regresních metod pro odhad výšky postavy. Jsou zde uvedeny také některé bližší informace o populacích, pro něž byly metody vytvořeny. Populace jsou bud' vyjmenovány, nebo označeny tř́íísmennou mezinárodní zkratkou státu. M označuje muže a F ženy.

jsou zcela zanedbatelné. Anatomické metody jsou tedy obecně nejpřesnější metody, které jsou $\mathrm{k}$ dispozici, a lze je doporučit vždy, kdy stav zachovalosti skeletu umožní jejich užití. Doporučujeme používat metodu Raxterové et al. (2006), definice jimi užívaných rozměrů uvádíme ve schématu IV. V př́ípadě, že některé složky kosterní výšky chybějí, doporučujeme pokusit se je odhadnout podle Auerbacha (2011). Postup při výběru metody pro odhad výšky postavy, který považujeme za vhodný, je znázorněn na schématu III.

Žádná bezchybná metoda pro odhad výšky postavy na základě skeletu v současnosti neexistuje. Do dnešní doby byly vytvořeny stovky metod, každá $\mathrm{z}$ nich má ovšem svá úskali a hodí se k použití jen za určitých podmínek. Jejich nahodilé používání vede $\mathrm{k}$ výsledkům, které mohou být leckdy méně přesné, než laický odhad od oka. Znalost principů a předpokladů užití metod je nejspolehlivějším nástrojem, jak se v konkrétních př́ípadech vyvarovat jejich chybnému výběru a minimalizovat riziko chyby odhadu $\mathrm{z}$ takového výběru plynoucí. Vychýlení odhadu může být i důsledkem jiných okolností, zcela záměrně jsme se vyhnuli otázce reprezentativnosti vzorku a mezipopulačních rozdílů $\mathrm{v}$ tělesných proporcích, které patří bezesporu $\mathrm{k}$ důležitým faktorům přesnosti odhadu výšky postavy. Domníváme se však, že vliv výběru vhodné metody je $\mathrm{z}$ hlediska přesnosti odhadu minimálně stejně důležitý.

\section{PODĚKOVÁNÍ}

Náš velký dík patř́i všem odborníkům, kteří svými opravami, komentáři a cennými radami přispěli ke zlepšení první verze tohoto článku. Jmenovitě jsou to: Marie Budíková, Ladislava Horáčková, Eduard Fuchs, Stanislav Katina, Petr Velemínský a Michal Živný. Děkujeme také anonymním recenzentům za velice př́nosné podněty a návrhy. Ladislavu Nejmanovi vděčíme za pomoc při překladu abstraktu do angličtiny. Př́iprava tohoto článku byla podpořena z projektu Aplikace metod analýzy obrazu a tvaru ve výzkumu biologie člověka (M. Králík, MUNI/A/0988/2009).

\section{LITERATURA}

Allbrook, D. (1961): The estimation of stature in British and East African males. Based on tibial and ulnar bone lengths. Journal of Forensic Medicine, 8(1), 15-28.

Anděl, J. (1986): Matematická statistika. Praha: SNTL.

Auerbach, B. M. (2011): Methods for estimating missing human skeletal element osteometric dimensions employed in the revised Fully technique for estimating stature. American Journal of Physical Anthropology, 145, 67-80.

Auerbach, B. M. - Ruff, C. B. (2010): Stature estimation formulae for indigenous North American populations. American Journal of Physical Anthropology, 141, 190-207. 
Bach, H. (1965): Zur Berechnung der Körperhöhe aus den langen GliedmaBenknochen weiblicher Skelette. Anthropologischer Anzeiger, 29, 12-21.

Beddoe, J. (1888): On the stature of the older races of England, as estimated from the long bones. The Journal of the Anthropological Institute of Great Britain and Ireland, 17, 201-209.

Breitinger, E. (1937): Zur Berechnung der Körperhöhe aus den langen Gliedmaßenknochen. Anthropologischer Anzeiger, 14, 249-274.

Černý, M. - Komenda, S. (1982): Reconstruction of body height based on humerus and femur lengths (material from Czech lands). II ${ }^{\text {nd }}$ Anthropological Congress of Aleš Hrdlička. Praha: Univerzita Karlova, 475-479.

Dobisíková, M. (2009): 8.1 Antropologické zhodnocení kosterních nálezů z Pavlova - Horního pole. In: J. Peška, Protoúnětické pohřebiště z Pavlova. Olomouc: Archeologické centrum Olomouc, 325-344.

Dobisíková, M. - Katina, S. - Velemínský, P. (2008): Stature of the Great Moravian Population in Connection with Social Status. In: P. Velemínský, L. Poláček (eds.), Studien zum Burgwall von Mikulčice, Band 8. Brno: Archäologisches Institut der Akademie der Wissenschaften der Tschechischen Republik, Brno, 77-91.

Dobisíková, M. - Velemínský, P. - Zocová, J. - Beran, M. (2000): Výpočet délky těla z délky dlouhých kostí. Smolenice 1999: Zborník referátov a posterov $z$ antropologických dní s medzinárodnou účastou, 25. - 26. 10. 1999. Bratislava: Slovenská antropologická spoločnost' pri SAV, 33-37.

Drozdová E. (2005): Břeclav - Pohansko. Slovanští obyvatelé velkomoravského hradiska Pohansko u Břeclavi. Brno: Masarykova univerzita.

Dwight, T. (1894): Methods of estimating the height from parts of the skeleton. Medical Record, 46, 293-296.

Duyar, İ. - Pelin, C. (2010): Estimating body height from ulna length: need of a population-specific formula. Eurasian Journal of Anthropology, 1(1), $11-17$.

Fojtová, M. - Dočkalová, M. - Jarošová, I. (2008): Antropologický rozbor koster ze sídlištních pohřbů moravského neolitu. Ve službách archeologie IX, 1/08, 213-221.

Fully, G. (1956): Une nouvelle méthode de détermination de la taille. Annales de médecine légale, criminologie, police scientifique et toxicologie, 36, 266-273.

Fully, G. - Pineau, H. (1960): Détermination de la stature au moyen du squelette. Annales de médecine légale, criminologie, police scientifique et toxicologie, 40, 146-153.

Galton, F. (1886): Regression towards mediocrity in hereditary stature. The Journal of the Anthropological Institute of Great Britain and Ireland, 15, 246-253.

Galton, F. (1888): Co-relations and their Measurement, chiefly from Anthropometric Data. Proceedings of the Royal Society of London, 45, 135-145.

Giannecchini, M. - Moggi-Cecchi, J. (2008): Stature in archeological samples from Central Italy: methodological issues and diachronic changes. American Journal of Physical Anthropology, 135, 284-292.

Humphry, G. M. (1858): A treatise on the human skeleton. Cambridge: Macmillan and Co.

Jones, H. E. (1937): Some geometrical considerations in the general theory of fitting lines and planes. Metron, 8, 21-31.

Kermack, K. A - Haldane, J. B. S. (1950): Organic correlation and allometry. Biometrika, 37(1-2), 30-41.

Lorencová, A. - Beneš, J. - Podborský, V. (1987): Těšetice - Kyjovice. 3, Únětické pohřebiště v Těšeticích - Vinohradech. Brno: Univerzita J. E. Purkyně.

Lundy, J. K. (1988): A report on the use of Fully's anatomical method to estimate stature in military skeletal remains. Journal of Forensic Sciences, 33(2), 534-539.

Manouvrier, L. (1893): La détermination de la taille daprès les grands os des membres. Mémoires de la Société d’Anthropologie de Paris, 4, 347-402.

Novotný, V. - İşcan, M. Y. - Loth, S. R. (1993). Morphologic and osteometric assessment of age, sex, and race from the skull. In: M. Y. İşcan - R. Helmer (eds.), Forensic Analysis of the Skull. Wiley-Liss, Inc.: New York, 71-88.

Olivier, G. (1963): Lestimation de la stature par les os longs des membres. Bulletins et Mémoires de la Société d'Anthropologie de Paris, 4(3), 433-449.

Orfila, M. J. de B. - Lesueur, M. O. (1831): Traité des exhumation juridique et considérations sur les changemens physiques que les cadavres éprouvent en se pourrissant dans la terre, dans leau, dans les fosses daisance et dans le fumier. Sv. II. Paris: Béchet Jeune.

Parker, G. H. (1909): A mechanism for organic correlation. The American Naturalist, 43, 212-218.

Pearson, K. (1896): VII. Mathematical Contributions to the Theory of Evolution. - III. Regression, Heredity, and Panmixia. Philosophical transactions of the Royal society of London, Series A, 187, 253-318.

Pearson, K. (1899): IV. Mathematical contribution to the theory of evolution. -- V. On the reconstruction of the stature of prehistoric races. Philosophical Transactions of the Royal Society of London, Series A, 192, 169-244.

Pearson, K. (1901): LIII. On lines and planes of closest fit to systems of points in space. Philosophical Magazine, 2, 559-572.

Raxter, M. H. - Auerbach, B. M. - Ruff, C. B. (2006): Revision of the Fully technique for estimating statures. American Journal of Physical Anthropology, 130, 374-384.

Raxter, M. H. - Ruff, C. B. - Auerbach, B. M. (2007): Technical note: revised Fully stature estimation technique. American Journal of Physical Anthropology, 133, 817-818.

Rollet, E. (1888): De la mensuration des os longs des membres dans ses rapports avec l'anthropologie, la clinique et la médecine judiciaire. Lyon - Paris: Storck - Steinheil.

Rösing, F. W. (1988): Körperhöhenrekonstruktion aus Skelettmaßen. In: R. Knußmann (ed.): Anthropologie. Handbuch der vergleichenden Biologie des Menschen. Wesen und Methoden der Anthropologie. Band I, 1. Teil. Stuttgart - New York: Gustav Fischer Verlag, 586-600.

Roos, C. F. (1937): A general invariant criterion of fit for lines and planes where all variates are subject to error. Metron, 8, 3-20.

Sciulli, P. W. - Schneider, K. N. - Mahaney M. C. (1990): Stature estimation in prehistoric Native Americans of Ohio. American Journal of Physical Anthropology, 83, 275-280.

Sjøvold, T. (1990): Estimation of stature from long bones utilizing the line of organic correlation. Human Evolution, 5(5), 431-447.

Snow C. C. - Williams J. (1971): Variation in premortem statural measurements compared to statural estimates of skeletal remains. Journal of Forensic Sciences, 16, 455-464.

Stloukal M. - Vyhnánek L. (1976): Slované z velkomoravských Mikulčic. Praha: Academia.

Sue, M. (1750): Sur les proportions du squelette de lhomme, Examiné depuis lâge le plus tendre, jusqu' à celui de vingt-cinq, soixante ans, \& au delà Mémoires présentés a l'Académie des Sciences, 572-585.

Sue, M. (1765): Anthropotomie, ou, Lart d'injecter, de disséquer, d'embaumer et de conserver les parties $d u$ corps humain, \& $c$. Paris: Cavellier.

Suchý, J. (1967): Postkraniální skelet. In: V. Fetter a kol., Antropologie. Praha: Academia, 154-173.

Teissier, G. (1948): La relation dallometrie sa signification statistique et biologique. Biometrics, 4(1), 14-53.

Telkkä, A. (1950): On the prediction of human stature from the long bones. Acta Anatomica, 9(1-2), 103-117.

Terry, R. J. (1940): On measuring and photographing the cadaver. American Journal of Physical Anthropology, 26, 433-447.

Topinard, P. (1885a): Éléments d'anthropologie générale. Paris.

Topinard, P. (1885b): Procédé de mensuration des os longs, dans le but de reconstituer la taille. Bulletins de la Société d'anthropologie de Paris, 8(8), 73-83.

Trotter, M. - Gleser, G. C. (1951): The effect of ageing on stature. American Journal of Physical Anthropology, 9(3), 311-324.

Trotter, M. - Gleser, G. C. (1952): Estimation of stature from long bones of American Whites and Negros. American Journal of Physical Anthropology, 10(4), 463-514.

Trotter, M. - Gleser, G. C. (1958): A re-evaluation of estimation of stature based on measurements of stature taken during life and of long bones after death. American Journal of Physical Anthropology, 16(1), 79-123.

Vercellotti, G. - Agnew, A. M. - Justus, H. M. - Sciulli, P. W. (2009): Stature estimation in an early medieval (XI-XII c.) Polish population: testing the accuracy of regression equations in a bioarcheological sample. American Journal of Physical Anthropology, 140, 135-142.

Živný, M. (2010): Antropologické zpracování lidských kosterních pozůstatku ze hřbitova u kostela sv. Jakuba v Brně. Výsledky paleodemografické a osteometrické analýzy. Brno: Akademické nakladatelství CERM. 


\section{AUTOŘI}

Zeman, Tomáš (1986), antropolog, absolvent Ústavu antropologie Př́rodovědecké fakulty Masarykovy univerzity a doktorský student téhož ústavu. Zabývá se odhady výšky postavy a proporcionalitou lidského těla.

Kontakt: Ústav antropologie Př́rodovědecké fakulty Masarykovy univerzity,

Kotlářská 2, 61137 Brno

e-mail: <222918@mail.muni.cz>
Králík, Miroslav (1973), antropolog; v současnosti působí jako docent Ústavu antropologie Prŕrodovědecké fakulty Masarykovy univerzity. Zabývá se sexuálním dimorfismem u živého člověka a na kostře člověka, a dále analýzou lidských stop na archeologických nálezech.

Kontakt: Ústav antropologie Př́rodovědecké fakulty Masarykovy univerzity,

Kotlářská 2, 61137 Brno

e-mail: <mirekkralik@seznam.cz> 